
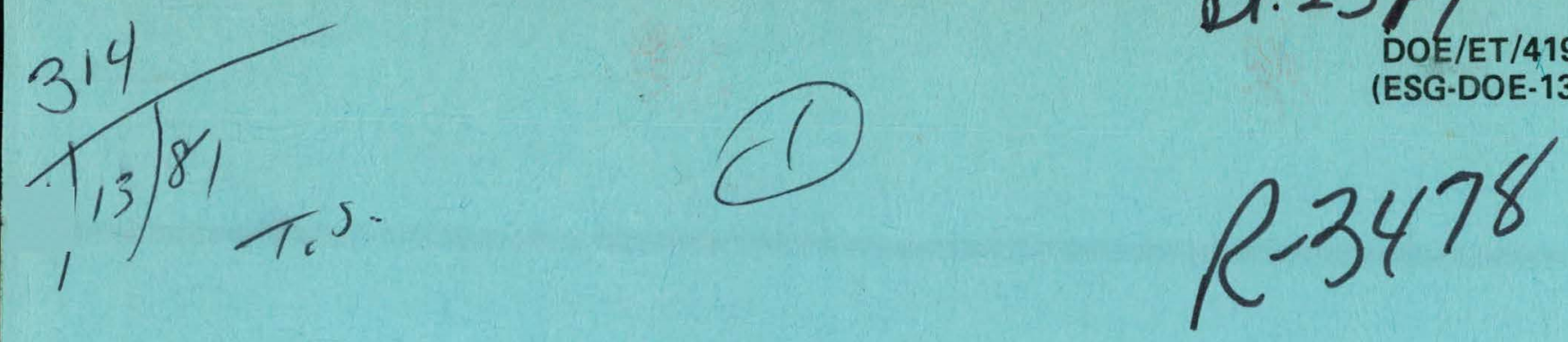

\title{
RADIATION AND TRANSMUTATION EFFECTS
}

RELEVANT TO

SOLID NUCLEAR WASTE FORMS

DOE Research and Development Report

\section{MASTER}

Prepared for the United States

Department of Energy,

Savannah River Operations Office

under Contract Number DE-ACO9-79ET41900 


\section{DISCLAIMER}

This report was prepared as an account of work sponsored by an agency of the United States Government. Neither the United States Government nor any agency Thereof, nor any of their employees, makes any warranty, express or implied, or assumes any legal liability or responsibility for the accuracy, completeness, or usefulness of any information, apparatus, product, or process disclosed, or represents that its use would not infringe privately owned rights. Reference herein to any specific commercial product, process, or service by trade name, trademark, manufacturer, or otherwise does not necessarily constitute or imply its endorsement, recommendation, or favoring by the United States Government or any agency thereof. The views and opinions of authors expressed herein do not necessarily state or reflect those of the United States Government or any agency thereof. 


\section{DISCLAIMER}

Portions of this document may be illegible in electronic image products. Images are produced from the best available original document. 


\section{NOTICE}

This report was prepared as an account of work sponsored by the United States Government. Neither the United States nor the United States Department of Energy, nor any of their employees, nor any of their contractors, subcontractors, or their employees, makes any warranty, express or implied, or assumes any legal liability or responsibility for the accuracy, completeness or usefulness of any information, apparatus, product or process disclosed, or represents that its use would not infringe privately owned rights.

Printed in the United States of America

Available from

National Technical Information Service

U.S. Department of Commerce

5285 Port Royal Road

Springfield, Virginia 22161

NTIS price codes

Printed copy: $\$ 7.00$

Microfiche copy: A01 


\section{RADIATION AND TRANSMUTATION EFFECTS}

RELEVANT TO

SOLID NUCLEAR WASTE FORMS

\section{By}

\section{E. R. VANCE \\ R. ROY}

K. K. S. PILLAY

The Materials Research Laboratory

The Pennsylvania State University

University Park, Pennsylvania

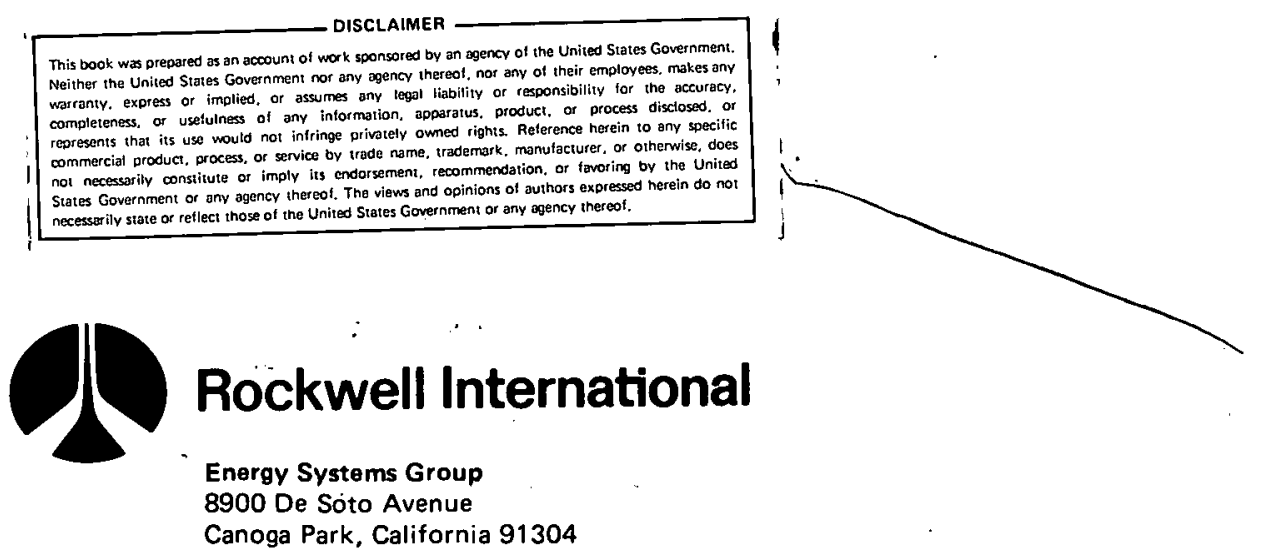

CONTRACT: DE-AC09-79ET41900

ISSUED: MARCH 15, 1981 


\section{DISTRIBUTION}

This report has been distributed according to the category "Nuclear Waste Management," as given in the Standard Distribution for Unclassified Scientific and Technical Reports, DOE/TIC-4500. 


\begin{abstract}
Radiation effects in insulating solids are discussed in a general way as an introduction to the quite sparse published work on radiation effects in candidate nuclear waste forms other than glasses.

Likely effects of transmutation in crystals and the chemical mitigation strategy are discussed.

It seems probable that radiation effects in solidified HLW will not be serious if the actinides can be wholly incorporated in such radiation-resistant phases as monazite or uraninite.
\end{abstract}


THIS PAGE

WAS INTENTIONALLY

LEFT BLANK 


\section{CONTENTS}

Abstract. ................................... 3

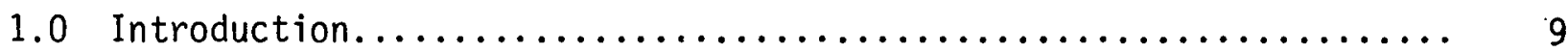

2.0 Radiation Effects in Solids: General Discussion.............. 16

2.1 Ionization Effects.......................... 16

2.2 Displacement Effects.......................... 17

2.3 Structural Sensitivity to Radiation.................... 19

2.4 Radiation-Induced Property Changes Relevant to Radwaste

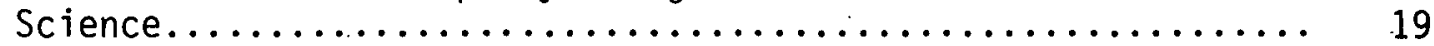

3.0 Work on Radiation Studies in Candidate Nuclear Waste Forms........ 21

3.1 Commercial HLW................................ 21

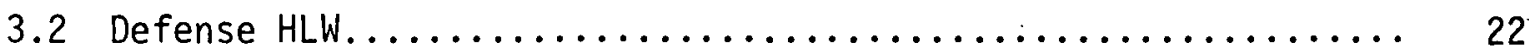

4.0 Likely Radiation Effects on Solidified Nuclear Waste Forms........ 24

5.0 Radiation Simulation Methods for Solid Waste Forms............ 26

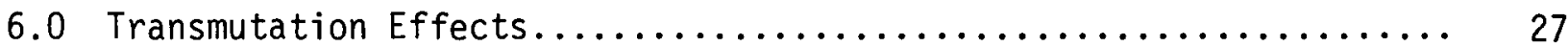

6.1 Fundamental Transmutation Studies.................... 28

6.2 Chemical Mitigation Studies...................... 30

6.3 The Transmutation Problem in Specific Radwaste Formulations.................................... 30

7.0 Conclusions and Final Remarks..................... 32

References.................................... 33

\section{TABLES}

1. Chemistries of High-Level Nuclear Wastes From Reprocessing....... 7

2. Yields of Stable (or Long-lived) Fission Products from Thermal

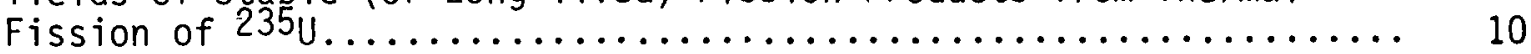

3. Atomic Displacements Due to Different Radiations.............. 12

4. Radiation Doses in Nuclear Waste Forms.................... 14

5. Various Kinds of Atom Displacement-Producing Techniques......... 15

6. Relatively Abundant Fission Product Elements for Which a Valence Change Will Occur in a Solid Waste Form and Which Have $t_{1 / 2}<1$ 


\section{FIGURES}

1. Alpha, Neutron, and Beta Doses to Wastes.

2. Time Evolution of $\alpha, \beta$, and Spontaneous Fission Dose in a Reference Borosilicate-Glass Containing 20 Weight Percent of

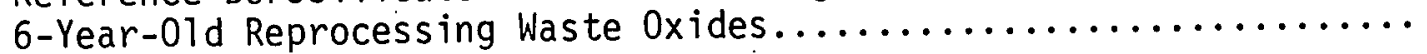




\subsection{INTRODUCTION}

Self-irradiation and transmutation effects in solidified nuclear waste forms could be of considerable significance. The general idea that radiation effects will be deleterious is based on the well-known lattice disruption and dimensional changes, and the increased rate of etching ("fission track" development) in some radiation-damaged solids, both crystalline and vitreous. Radiolysis effects might also be expected to be damaging because of the very reactive nature of radiation-induced free radicals. However, such generalities are of little value in evaluating quantitatively the actual radiation effects on the properties of a particular waste form, and the quantitative effect on the waste package system.

Over the last 30-odd years; there has been a great deal of work on fundamental radiation effects in all types of solids. In the present report, such radiation-effects research in nonmetallic inorganic solids will be reviewed in a general way. Since it seems unlikely that solid waste forms will be metallic (an electrolyticaliy made metallic form was, however, proposed recentiy (1)) apart from the use of metals as encapsulants or canisters, there will be little discussion of radiation effects in metals.

Information on radiation effects in candidate solid nuclear waste forms is quite sparse but will be briefly discussed. Attention will be drawn to crystalline phases known to have substantial radiation resistance. There have been some recent reviews along these 1 ines, $(2-4)$ but the emphases in the present work will be somewhat different.

Transmutation effects might also cause difficulties in nonmetallic waste forms. When a nuclide radioactively decays, the daughter ion may be chemically different to the parent. Thus although the parent nuclide may fit into the waste form at the atomic levë1, the daughter ion may not so fit and the waste form would then be rendered further from thermodynamic equilibrium. This effect will be discussed in more detail in Section 6 , but the bulk of this report will be concerned with radiation effects. 
TABLE 1

CHEMISTRIES OF HIGH-LEVEL NUCLEAR WASTES FROM. REPROCESSING

\begin{tabular}{l|r|r|r|r}
\hline \multirow{2}{*}{ Component. } & \multicolumn{4}{|c}{ Mole Percent } \\
\cline { 2 - 5 } & PW-4b & PW-7 & PW-7a & PW-8a \\
\hline Rare earths & 26.4 & 30.9 & 20.5 & 6.7 \\
$\mathrm{Zr}$ & 13.2 & 9.2 & 6.1 & 3.5 \\
$\mathrm{Mo}$ & 12.2 & 8.2 & 5.5 & 3.2 \\
$\mathrm{Ru}$ & 7.6 & 5.1 & 3.4 & 2.0 \\
$\mathrm{Cs}$ & 7.0 & 4.7 & 3.1 & 1.8 \\
$\mathrm{Fe}$ & 6.4 & 8.7 & 5.8 & 30.0 \\
$\mathrm{Pd}$ & 4.1 & 2.8 & 1.8 & 1.1 \\
$\mathrm{Sr}$ & 3.5 & 2.3 & 1.6 & 0.9 \\
$\mathrm{Ba}$ & 3.5 & 2.3 & 1.6 & 0.9 \\
{$\left[\mathrm{P0}{ }_{4}\right]$} & 3.2 & 8.7 & 5.8 & 1.7 \\
$\mathrm{U}$ & 1.4 & 9.6 & 6.3 & 3.7 \\
$\mathrm{Rb}$ & 1.3 & 0.9 & 0.6 & 0.3 \\
$\mathrm{Na}$ & $-\mathrm{n}$ & 0.9 & 34.0 & 40.0 \\
$\mathrm{Am}+\mathrm{Cm}+\mathrm{Pu}$ & 0.2 & 0.2 & 0.2 & 0.1 \\
$\mathrm{Others}$ & 9.8 & 5.5 & 3.7 & 4.1 \\
\hline
\end{tabular}

PW is U.S. Energy Research and Development Administration shorthand for Purex process wastes. PW-4b and PW-7 are "clean".HLW's. (Clean is equivalent to low sodium.)

PW-7a and PW-8a are "dirty." (Dirty is equivalent to high sodium.)

PW-7 contains an excess of gadolinium used as a neutron absorber plus more iron, $\left[\mathrm{PO}_{4}\right]$, uranium, and some sodium.

PW-8a is typical of HLW in storage at Nuclear Fuel Services, West Valley, New York.

Data from Reference 7 . 
The important radioactive decay particles in nuclear wastes are $\alpha$-particles, $\alpha$-recoil nuclei, $\beta$ - and $\gamma$-rays, neutrons, and fragments from spontaneous fission. The chemical compositions of HLW from reprocessing are shown in Table 1 . The content of long-lived radioactive nuclides in fission products is indicated in Table 2. The time evolution of the $\alpha, \beta$, and neutron productions in the (reprocessed) waste from 1 tonne of heavy metal fuel has been given by Roberts et al. (See Figure 1 ). Whereas $\beta$ - and $\gamma$-rays reputediy (see below) produce essentially only ionization effects (electron-hole pairs), $\alpha$-rays and, more importantly, $\alpha$-recoil nuclei produce significant numbers of atomic displacements (Table 3 ). Based on calculations such as those shown in Table 2 and those of Roberts et a1., (5) Malow and Andresen ${ }^{(6)}$ have calculated the time evolution of the number of atomic displacements from $\alpha, \beta$, and fission events in a reference waste form (20\% of 6-year-old waste oxides from commercial reprocessing, in borosilicate glass) and also give the time evolution of the number of $\alpha$-events $: \mathrm{cm}^{-3}$ in the reference waste form (see Figure 2) Using the data. of References 5 and 6 , we calculated the $\alpha$ - and $\beta$-doses for $10^{3}$ and $10^{6}$ year's for wastes of various ages (see Table 4).

The above calculations however, refer only to atomic displacements calculated by the basic methods of Kinchin and Pease ${ }^{(9)}$ and self-annealing and displacements due to ionization effects (radiolysis) are ignored. However, for fission-fragment irradiated zircon, zirconia, $\alpha$-alumina, and $\mathrm{U}_{3} \mathrm{O}_{8}$ it can be deduced $(11-14)$ that each fission event produced $-10^{6}-10^{7}$ displaced atoms, a value much higher than those given in Table 3 . Very recently, Hobbs and co-workers $(15-17)$ have rendered quartz amorphous by electron irradiation, and have attributed the effects to radiolysis, not classical atom displacement. Though it is suggested (16) that the $\beta / \gamma$ self-irradiation of silicate-based solid waste media could produce comparable effects to $\alpha$-recoil events, quantitative justification of the proposal is presently lacking - particularly as the radiolysis experiments are influenced by the quantities of $\mathrm{H}_{2} \mathrm{O}$ in the quartz and are carried out at very high electron-beam current densities. Effects of purely ionizing radiation have also been studied in vitreous silica and density changes have been observed; again radiolysis effects would seem to be responsible. $(18-19)$ 
TABLE 2

YIELDS OF STABLE (OR LONG-LIVED)* FISSION PRODUCTS FROM: THERMAL FISSION OF $235 \mathrm{U}$

\begin{tabular}{|c|c|c|c|c|c|c|c|c|c|c|}
\hline$(Z)$ & ) Element & $A_{R}$ & $\%$ Yield $^{\dagger}$ & $\underset{(\%)}{\text { Radioactive }}$ & $t_{1 / 2}$ Year & (Z) Element & $A_{R}$ & $\%$ Yield $^{\dagger}$ & $\underset{(\%)}{\text { Radioactive }}$ & $t_{1 / 2}$ Year \\
\hline (34) & Selenium & 79 & 0.4 & 11 & $\sim 6 \times 10^{4}$ & (50) Tin & 126 & 0.1 & 37 & $1 \times 10^{5}$ \\
\hline (35) & Bromine & & 0.3 & - & $s$ & (51) Antimony & 125 & 0.1 & 30 & 2.7 \\
\hline (36) & Krypton & & 3.8 & & & (52) Tellurium & & 2.5 & - & $s$ \\
\hline (37) & Rubidium & & 1.3 & - & s & (53) Iodine & 129 & 1.0 & 83 & $1.6 \times 10^{7}$ \\
\hline (38) & Strontium & 90 & 6.2 & 60 & 29 & (54) Xenon & & 20 & & \\
\hline (39) & Yttrium & & 4.8 & - & s & (55) Cesium & $\begin{array}{l}134 \\
135 \\
137\end{array}$ & 20 & $\begin{array}{r}5 \\
15 \\
44\end{array}$ & $\begin{array}{l}2 \\
3 \\
30\end{array}$ \\
\hline$(40)^{\circ}$ & Zirconium & 93 & 36.9 & 20 & $1.5 \times 10^{6}$ & (56) Barium & & 6.7 & - & 5 \\
\hline (41) & Niobium & & $<0.1$ & - & & (57) Lanthanum & & 6.6 & - & 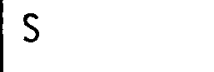 \\
\hline (42) & Molybdenum & & 25.1 & - & $S$ & (58) Cerium & 144 & 12.3 & 2 & 0.8 \\
\hline (43) & Technetium & 99 & 6.1 & 100 & $2 \times 10^{5}$ & (59) Praseodymium & & 5.9 & - & $S$ \\
\hline (44) & Ruthenium & 106 & 9.3 & 5 & 1.0 & (60) Neodymium & & 20,5 & - & $S$ \\
\hline (45) & Rhodium & & 4.9 & - & s & (61) Promethium & 147 & 2.3 & 100 & 2.6 \\
\hline (46) & Palladium & 107 & 1.4 & 15 & $7 \times 10^{6}$ & (62) Samarium & 151 & 1.9 & 5 & 90 \\
\hline (47) & Silver & & 0.2 & - & s & (63) Europium & $\begin{array}{l}154 \\
155\end{array}$ & 0.2 & $\begin{array}{r}\sim 28 \\
2\end{array}$ & $\begin{array}{l}85 \\
49\end{array}$ \\
\hline (48) & Cadmium & & 0.1 & - & s & (64) Gadolinium & & $<0.1$ & - & $s$ \\
\hline (49) & Indium & & $<0.1$ & - & s & & & & & \\
\hline
\end{tabular}

$*^{*} t_{1 / 2}>0.5$ year

to Yield is the number of atoms per 100 fissions

$A_{R}=$ atomic weight of radioactive isotope

$S=$ stable

Data from Reference 8 


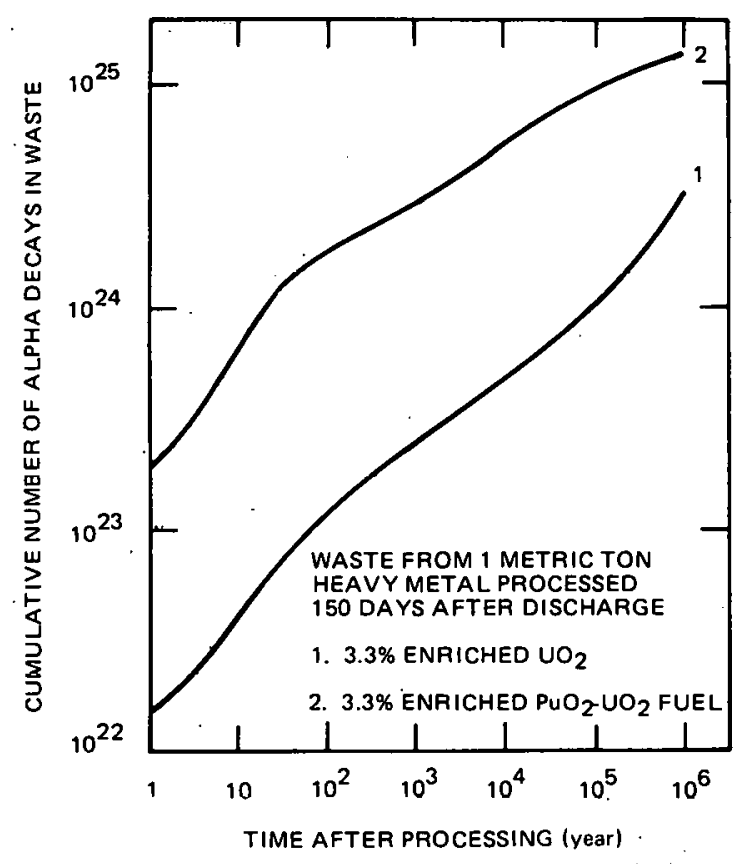

a. Alpha Dose to Wastes

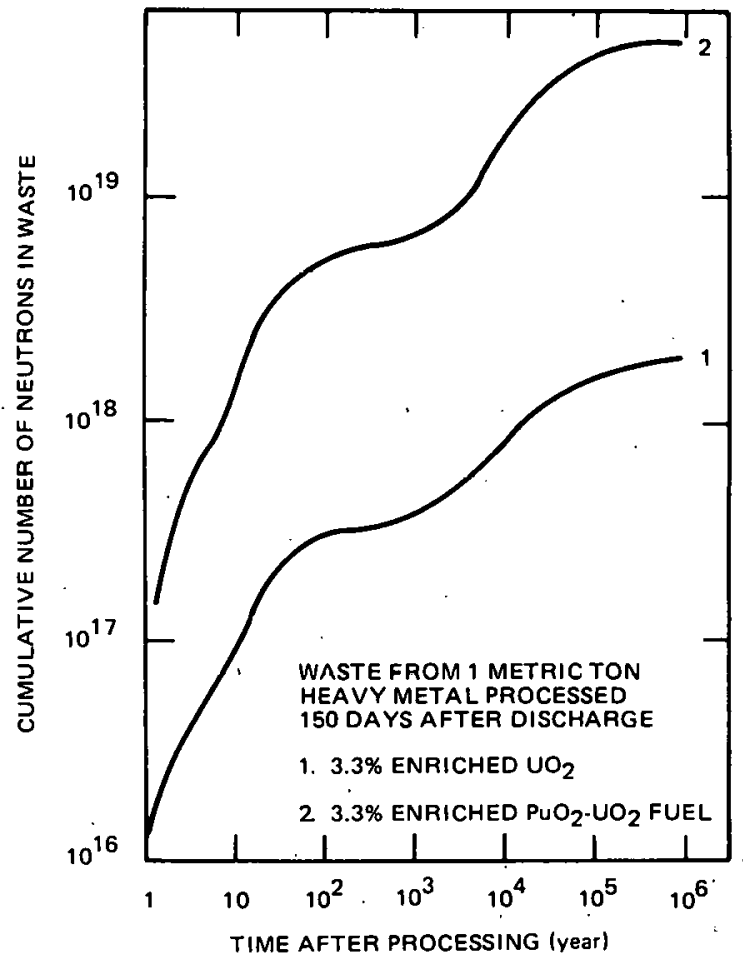

b. Neutron Dose to Wastes

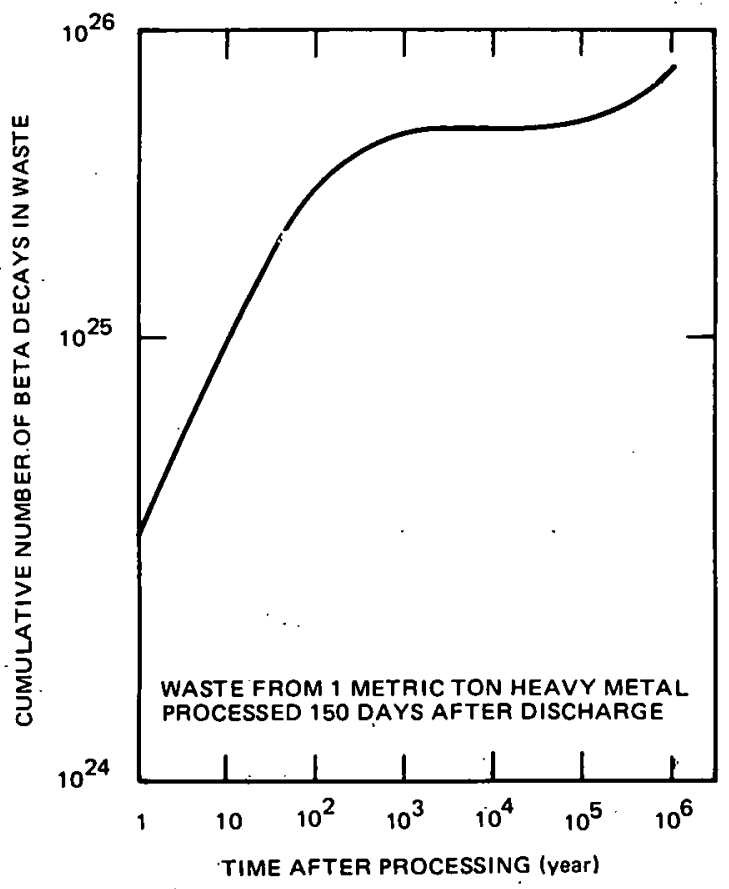

c. Beta Dose to Wastes

Figure 1. Alpha, Neutron, and Beta Doses to Wastes (see Reference 5) 
TABLE 3

ATOMIC DISPLACEMENTS DUE TO DIFFERENT RADIATIONS

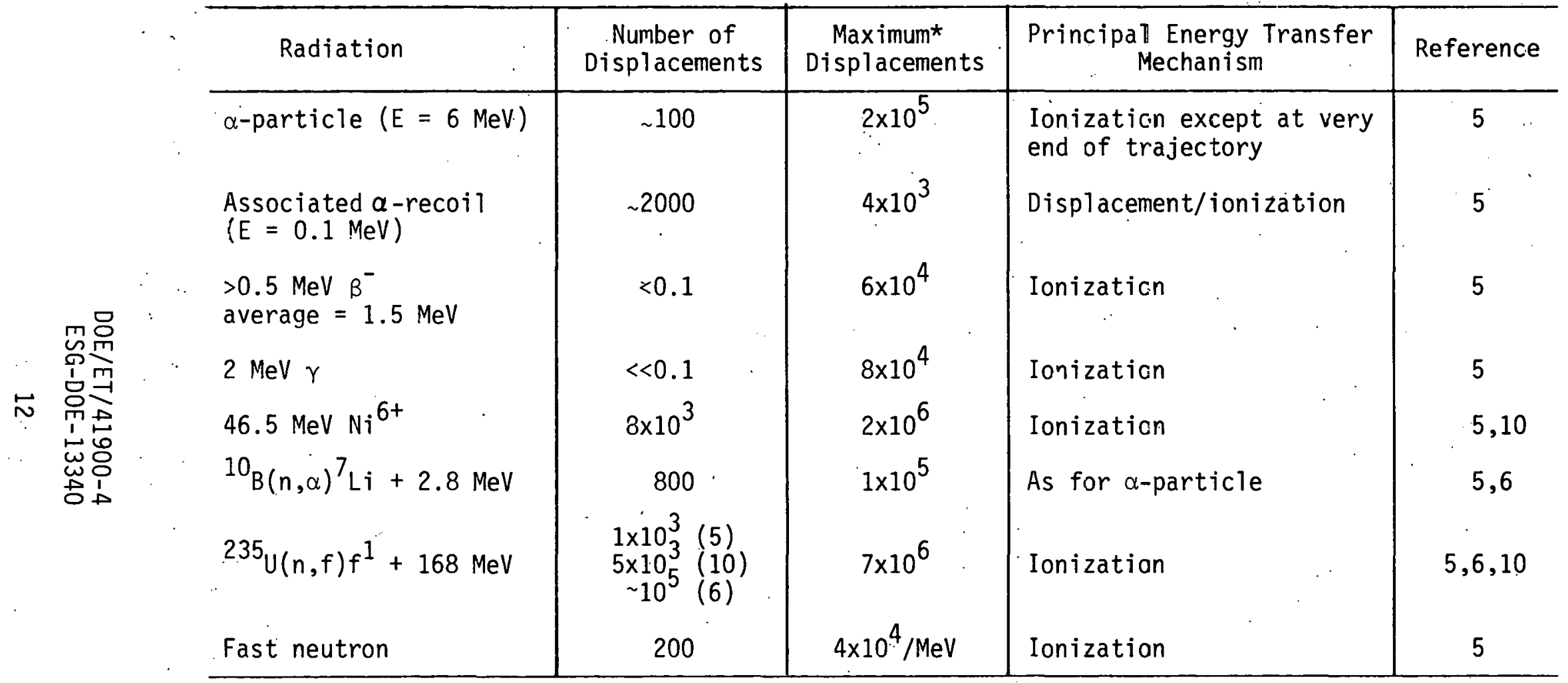

* (Incorrectly) assuming (a) all energy used for bond-breaking and (b) displacement energy $=25$ e. $\mathrm{v}$. 

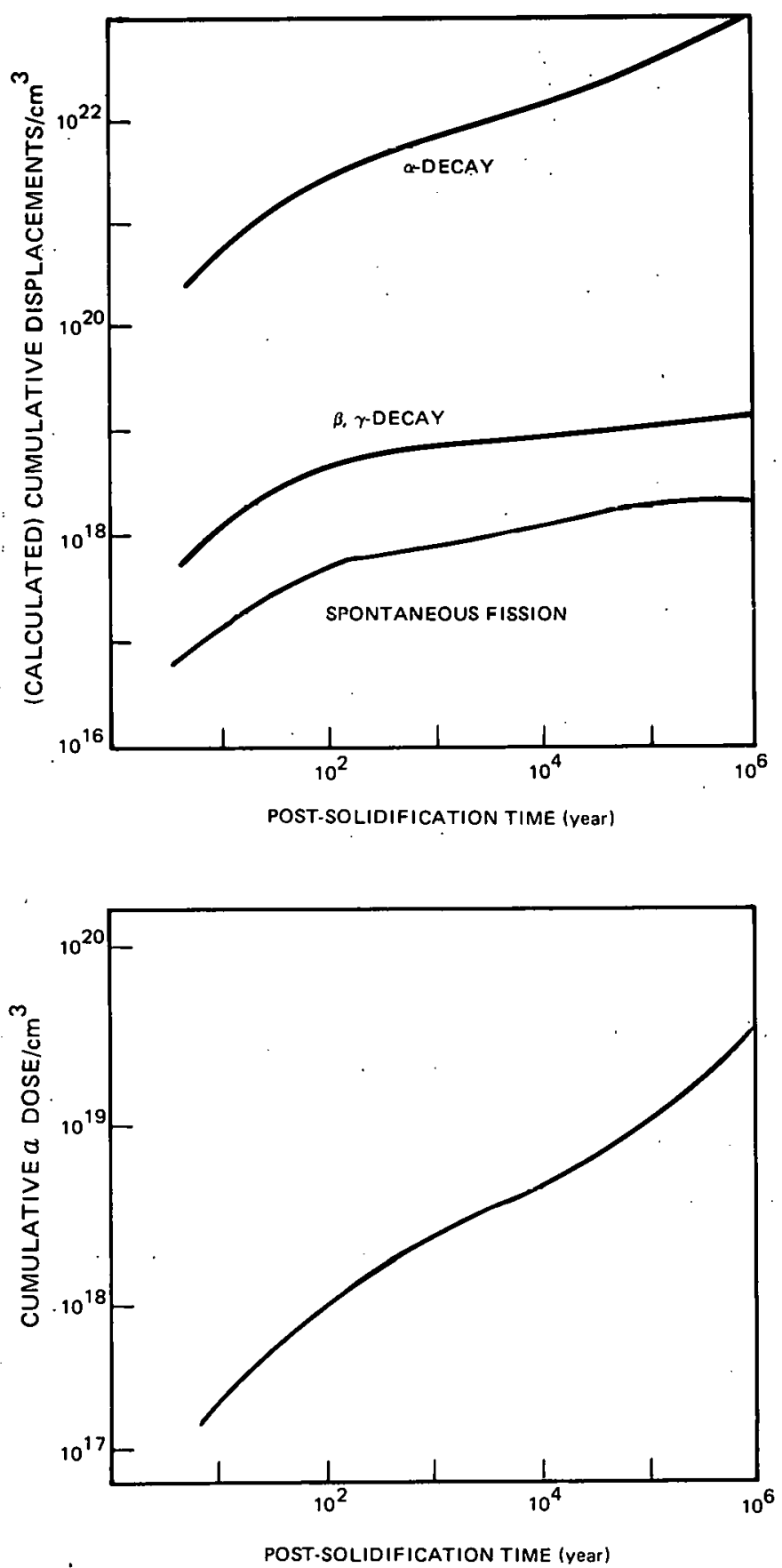

Figure 2. Time Evolution of $\boldsymbol{\alpha}, \boldsymbol{\beta}$, and Spontaneous Fission Dose in a Reference Borosilicate-Glass Containing 20 Weight Percent of 6-Year-01d Reprocessing Waste 0xides (After Reference 6)

$\mathrm{DOE} / \mathrm{ET} / 41900-4$

ESG-DOE- 13340 
TABLE 4

RADIATION DOSES IN NUCLEAR WASTE FORMS

(Commercial Waste - 20 waste oxides in borosilicate glass)

\begin{tabular}{|c|c|c|c|}
\hline \multirow[b]{2}{*}{ Dose } & \multicolumn{3}{|c|}{$\begin{array}{l}\text { age of waste } \\
(y r)\end{array}$} \\
\hline & 1 & 10 & 50 \\
\hline \multicolumn{4}{|c|}{ cumulative dose $\left(\mathrm{cm}^{-3}\right)$ after $10^{3}$ years } \\
\hline $\begin{array}{l}\alpha \text { dose } \\
\beta \text { dose }\end{array}$ & $\begin{array}{l}2.0 \times 10^{18} \\
1.9 \times 10^{20}\end{array}$ & $\begin{array}{l}1.7 \times 10^{18} \\
1.3 \times 10^{20}\end{array}$ & $\begin{array}{l}1.3 \times 10^{18} \\
1.0 \times 10^{20}\end{array}$ \\
\hline \multicolumn{4}{|c|}{ cumulative dose $\left(\mathrm{cm}^{-3}\right)$ after $10^{6}$ years } \\
\hline $\begin{array}{l}\alpha \text { dose } \\
\beta \text { dose }\end{array}$ & $\begin{array}{l}3.0 \times 10^{19} \\
3.1 \times 10^{20}\end{array}$ & $\begin{array}{l}3.0 \times 10^{19} \\
2.5 \times 10^{20}\end{array}$ & $\begin{array}{l}2.9 \times 10^{19} \\
2.2 \times 10^{20}\end{array}$ \\
\hline
\end{tabular}

These values were calculated from the results, of References 5 and 6. Values for defense wastes will'be $10^{2}$ less in each case, but precise values will depend on the actual composition of the waste form.

To make laboratory studies which relate to the radiation response of a solidified waste form for many years after solidification, it is clearly necessary to use accelerated testing. For $\alpha$-recoil damage, this can be done most directly by incorporating short-lived $\alpha$-emitters such as ${ }^{236} \mathrm{Pu},{ }^{238} \mathrm{Pu}$, or ${ }^{244} \mathrm{Cm}$ in the waste form. However, a whole range of other possible irradiation techniques exists: fast neutrons, fast-neutron fission of ${ }^{235} U$ or ${ }^{238} U$, slow-neutron fission of ${ }^{235} \mathrm{U}$, slow-neutron reactions on ${ }^{10} \mathrm{~B}$ or ${ }^{6} \mathrm{Li}$, accelerated ions or "external" $\alpha$-sources. Each of these methods has obvious advantages and disadvantages (Table 5). In Section 5, the most appropriate tests for the radwaste problems will be discussed: 
TABLE 5

VARIOUS KINDS OF ATOM DISPLACEMENT-PRODUCING TECHNIQUES

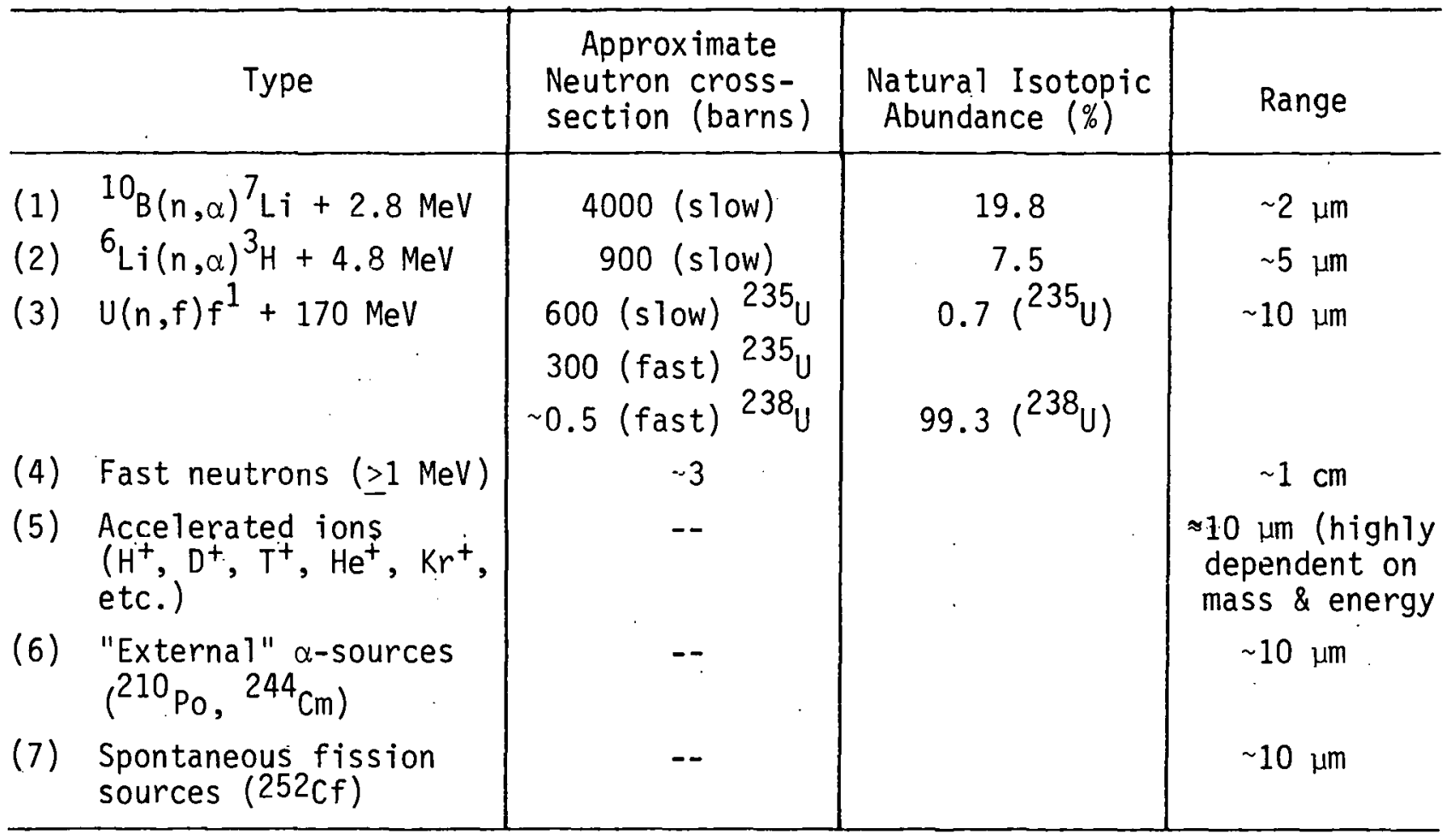

Comments

(1) $B$ may be difficult to disperse or dissolve in radwaste phases - unless dispersed at $<1 \mu \mathrm{m}$, self-absorption of $7_{\mathrm{L} i}, \alpha$ is a problem. However, $B$ may. substitute for A1.

(2) Same as (1), unless phase of interest contains alkali metals or, possibly, alkaline earth oxides.

(3) Even if insoluble, $U$ can be dispersed at $\sim 2 \mu \mathrm{m}$ scale in ceramic phases so self-absorption problem relatively unimportant.

(4) Wide energy spectrum and different atomic masses and scattering crosssections makes detailed calculations difficult:

(5) Unless using very light, very energetic ions, only a thin layer of target is irradiated -- so substrate epitaxy complications ensue. Damage profile nonuniform even in irradiated layer -- leads to characterization difficulties. Also very difficult to avoid sample heating effects, with consequent annealing phenomena.

(6) As for (5), very thin and depth-dependent damage profiles. Intrinsic dose limit, because only a-emitting atoms within $\sim 10 \mu \mathrm{m}$ of the surface of the source can provide $\alpha$-particles which may emerge from the source.

(7) As for (6), fission flux $\sim 3 \%$ of $\alpha-f 7 u x$. 


\subsection{RADIATION EFFECTS IN SOLIDS: GENERAL DISCUSSION}

\subsection{IONIZATION EFFECTS}

All crystalline solids contain lattice defects such as solid solution impurities, second-phase material, grain boundaries, coherent precipitates, surfaces, voids, vacancies, dislocations, etc. These defects perturb the nominally periodic charge distribution, and the lattice can be regarded as the sum of a periodic charge distribution plus a set of impurity charges located at the various lattice imperfections. (These impurity charges are largely screened out by the conduction electrons in metals.) When electron-hole pairs are created by ionizing radiation in non-metals, electrons can be trapped by positive impurity charges and vice-versa for holes. If the localized impurity charge in a non-metal can only bind one electron or hole, a hydrogen atom model will describe the gross features of the impurity and electron (hole) system, but if more than one electron (hole) can be bound, the gross description will be that of a He, ... atom. All these systems constitute color centers (bound excitons in a semiconductor) though, of course, if their principal allowed transitions do not lie in the optically-visible region (1.8-3.0 e.v.), no actual coloration will be observed.

The formation and bleaching kinetics of these defect systems can be followed with various spectroscopic techniques. An important point is that (neglecting radiolysis effects) the number of these defects saturates with ionization dose, the limiting feature being the number of lattice imperfections in the solid.

Another effect of ionizing radiation is radiolysis of organic molecules, water, anions and (light) alkali halides: this effect is essentially radiodecomposition of the molecules by the formation of an (unstable) highly-excited state of the particular molecule. The radiolysis of water has been widely studied; the various radiolytic products formed are $\mathrm{H}^{+}, \mathrm{OH}^{-}, \mathrm{O}_{2}^{2-}, \mathrm{H}^{0}, \mathrm{O}^{-}, \mathrm{H}_{2} \mathrm{O}_{2}$, etc. These free radicals or atomic/molecular species are highly reactive and might be expected to produce gas buildup or uncontrolled chemical reactions on the solid nuclear waste form. However, in each radiolysis event, a free radical is accompanied by other radicals or electrons which, in a solid, will have a very strong tendency 
to recombine rather than react with the solid. As mentioned earlier, ionization maiy cause atomic displacements by solid-phase radiolysis in silicates.

\subsection{DISPLACEMENT EFFECTS}

To move an atom in a solid from its regular site, $\approx 25 \mathrm{e} . \mathrm{v}$. has to be imparted to the atom so that all the bonds to its neighbors are broken. Obviously, energy transfer from the radiation field to the nuclei critically depends on the mass of the bombarding particles. The approximate atomic displacement capabilities of various kinds of radiations were indicated in Table 4 .

The most detailed studies of atomic displacement damage have been made in simple solids, notably the lighter alkali and silver halides. In the former, as mentioned earlier, displacements giving rise to anion vacancies (F-centers when an electron is trapped) and, of course, associated anion interstitials, can be created by purely ionizing radiation. In the latter, the main phenomenon is the interconversion of $\mathrm{Ag}^{2+}, \mathrm{Ag}^{+}$, and $\mathrm{Ag}^{0}$. The alkaline earth oxides have also been studied in a fair amount of detail, using fast-electron and neutron irradiations.

Fast-neutron effects have been widely studied in covalent $\mathrm{SiO}_{2}$, graphite and diamond (for a review of the early work, see Reference 20).

The basic conclusions, derived from optical and electron paramagnetic resonance spectroscopy, X-ray diffraction, and dilatometry, are that at low doses and using not-too-massive particles, the Frenkel defect predominates. The vacancy may exist in a variety of charge states. In non-monatomic solids, it is the anion lattice, rather than the cation lattice, which is prone to displacements. Because of the extreme sensitivity in certain cases of electron paramagnetic resonance, a variety of surface radicals can be identified in irradiated powders, especially when different atmospheres' are provided.

At higher radiation doses (and irradiation temperatures) the point defects aggregate into multi-atomic defects and condense to form dislocation 1oops; X-ray patterns become diffuse (strictly speaking, for point defects, diffuse scattering 
builds up near reciprocal lattice positions at the expense of the Bragg scattering) and easily-measurable dimensional changes may occur. In general, irradiation of a crystalline material leads to a volume expansion or density decrease since an interstitial tends to expand the lattice more than the complementary vacancy contracts it. Such dimensional changes (which may however, be positive or negative) are also observed in glasses and "devitrification" of "amorphous" thin films may occur.

Generally speaking, only small dimensional changes occur in metals but radiation creep via the induced vacancies is important for load-bearing alloys. Radiation also enhances corrosion and may change order-disorder kinetics appreciably in alloys. Since optical and microwave spectroscopies are not viable for the study of defects in irradiated metals, basic studies have generally relied on low temperature $\left(-4^{0} \mathrm{~K}\right)$ irradiation and have mostly utilized studies of electrical resistivity.

Note that the above discussion is geared to point defects; for very heavy, energetic bombarding particles there will be an enhanced probability of relatively large groups of ions being more or less simultaneously displaced so that new phases with the same compositions as the parent solid could, in principle, form. Such a concept is inherent in the well-known "thermal spike" mechanism of radiation damage in solids, though it must be said that except possibly for fission fragment irradiation, there is very little evidence for such microphase formation. One possibility is the fission-fragment induced phase transformation in $\mathrm{ZrO}_{2}$, (13) although a recent discussion of this system did not favor the "thermal spike" mechanism. (15)

Quite a large, basically non-overlapping, literature exists on metamict minerals such as zircon which suffer radiation damage in nature due to incorporation of radioactive $\alpha$-emitters ( $U$, Th, and daughters) in their structures (or because they are geologically emplaced next to such radioactive-element-bearing materials). These studies are, by and large, much more phenomenological than the aforementioned radiation studies on synthetic structures because the natural minerals are structurally more complex (see References 21-23 for reviews). 


\subsection{STRUCTURAL SENSITIVITY TO RADIATION}

The sensitivity of refractory crystalline materials to radiation varies widely atthough there is general agreement that anisotropy of the structure is a key feature. (12,24) "Open" structures, with "holes" or "channels," should allow location of displaced atoms in metastable interstitial sites, rather than favor interstitialvacancy recombination, (25) though it was earlier argued that such a condition would not be sufficient for metamictization. (9) A further condition must be met; namely, the $T_{x}(\overline{26})$ or rapid crystallization temperature must be well above room temperature, i.e., formation in principle of a non-crystalline solid is not enough; it must also be retained at the temperature of observation. Several authors have also commented $(20,24)$ that covalent rather than ionic bonding promotes radiation. sensitivity. Of course, high bond strength is related to $T_{x}$.

\subsection{RADIATION-INDUCED PROPERTY CHANGES RELEVANT TO RADWASTE SCIENCES}

For radioactive waste management, characterization of structural changes in the waste form as a result of self-irradiation damage is of interest, but more information is required. Over $10^{6}$ years the density change of a HLW glass and, presumably, a (wel1) tailored ceramic form would be of the order of $1 \%$, from. accelerated ${ }^{244} \mathrm{Cm}$ doping tests. $(27,28)$ However, by far the most important properties of the glass or ceramic waste form are those of general reactivity and "solubility." or "leachability" in various possible groundwaters. Little definitive evidence on these questions exists, apart from the obvious fact that the very existence of very old metamict minerals in a variety of mineralogical environments establishes that the absolute "solubility" or "leachability" is not very large.

Haaker and Ewing (23) have argued that alteration of minerals is "enhanced" by metamictization but gave no quantitative data. Mumpton and Roy (16) tabulated the analyses of the products of a large number of hydrothermally-treated metamict zircons and showed that only in a few cases, was a small excess of $\mathrm{ZrO}_{2}$ present, possibly arising because the " $\mathrm{SiO}_{2}$ " in the amorphous $\mathrm{ZrSiO}_{4}$ was more easily available to attack by hydrothermal solutions. Most metamict zircons remained reasonably stoichiometric. Irradiated diamond etches (in molten $\mathrm{KNO}_{3}$ ) more rapidly after 
fast neutron damage, $(29)$ and the entire science of fission track etching in minerals, such as mica ${ }^{(30)}$ depends on the higher solubility of the damaged region. However, this "development" can only be brought about by very specific, corrosive etchants which selectively attack the damaged region. Fission tracks can, of course, also be "developed" in glasses $(32)$ showing that radiation effects in waste forms are in no way confined to crystalline materials. From crystal chemical considerations, radiation damage should be no more drastic in increasing "solubility" or "leachability". than non-crystalline solid formation (by means other than irradiation), but experiments are necessary to examine this proposition. For relatively isodesmic phases such as zircon or monazite where all the bond strengths are very high, the crystalline - noncrystalline transformation should make relatively little difference to solubility, since the weakest bonds (where attack occurs) are essentially uniffected. 


\subsection{WORK ON RADIATION STUDIES IN CANDIDATE NUCLEAR WASTE FORMS}

\subsection{COMMERCIAL HLW}

In prototype HLW glasses which were self-irradiated by ${ }^{244} \mathrm{Cm}$ incorporation, corresponding to $\alpha$-doses which would occur after $\sim 10^{5}$ years post-solidification storage in a "reference" glassy waste form, (5) no significant changes were observed in leach rate, density, etc. Again, no significant deterioration effects were

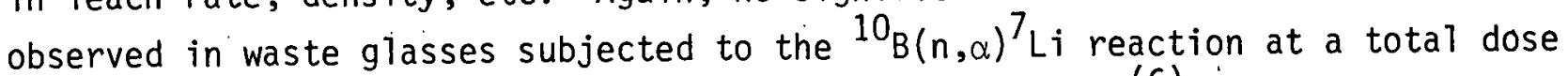
equivalent to $\sim 10^{5}$ years of storage after solidification. (6) Other studies in the U.K. support these results. (33)

Using fast fission of ${ }^{235} \mathrm{U}$ and (separately) accelerated $\mathrm{Ni}^{6+}$ ions in doses equivalent to $>10^{6}$ years of post-solidification self-irradiation, measurements of stored energy were made ${ }^{(11)}$ and no impairment of durability was observed. However, no leach tests were made and there was local heating of the specimen in the $\mathrm{Ni}^{6+}$ irradiation experiments which would have promoted annealing behavior.

HLW glasses which had been crystallized to a ceramic were studied by the ${ }^{244} \mathrm{Cm}$ irradiation technique, using a dose equivalent to $10^{3}$ years of irradiation, and again no deleterious effects were evident, although amorphization of certain of the devitrification phases was observed. (27)

For crystalline ceramic waste forms, information is very sparse, though the "PSU supercalcine-ceramic" $(7,34,35)$ showed no great changes of leach resistance on doping with ${ }^{244} \mathrm{Cm}$ such that equivalent doses of $10^{3}$ years storage were sustained. (28) However, the apatite phase was rendered amorphous: Although $\gamma$-irradiation of the (non-doped) supercalcine-ceramic is reported to have had some effect on its leaching behavior, ${ }^{(36)}$ this would presumably have been due to radiolysis of the leaching solution, certainly not displacement damage in the ceramic.

It seems that one can safely conclude that no major decrease in the durability of either glass or PSU-ceramic candidate commercial HLW forms will occur after $10^{5}$ 
or $10^{3}$ years of self-irradiation, respectively, but experiments are clearly necessary to extend these times by some orders of magnitude, in both these and new materials.

Several candidate crystalline radiophases were irradiated with doses of $\approx 10^{15}$ fission fragments $\cdot \mathrm{cm}^{-3}$. (37) It was deduced, however, that fission fragment irradiation is probably not a good simulator of $\alpha$-recoil damage, but that the technique has merit insofar as many candidate phases can be rendered X-ray amorphous, so that limiting leach rate and density changes on metamictization can be evaluated.

\subsection{DEFENSE HLW}

Since defense wastes have low radioactive loadings, 100 times lower than commercial wastes, it would be expected that radiation effects in non-partitioned defense wastes would be minor. This could well be the case, but since the actual chemistries of the defense wastes are completely different to those of commercial wastes -- the waste forms could be chemically very different also, unless dilution into borosilicate glass was used for both defense and commercial waste (the present "reference" process).

Essentially the only published information available is that on simulated Savannah River sludge diluted $\sim 1: 3$ with borosilicate glass and in which the $\alpha$-emission was produced by incorporation of ${ }^{238} \mathrm{Pu}$ or ${ }^{244} \mathrm{Cm} .{ }^{(38)}$ Oniy very small density changes were observed after $\sim 10^{6}$ years equivalent self-irradiation, and no significant leaching behavior changes were observed although some microcracking did take place. In the present work, a hot-pressed simulated Savannah River sludge-based ceramic showed no microcracking when doped with $\sim 1$ wt $\%{ }^{235} U$ and irradiated for 1,3 , and 10 hours in a neutron flux of $5 \times 10^{12} \mathrm{n} / \mathrm{cm}^{2} . \mathrm{s}$ (fast) $+1 \times 10^{13} \mathrm{n} / \mathrm{cm}^{2} . \mathrm{s}$ (thermal). This, however, was not surprising since the ranges of the fission fragments were considerably in excess of the grain size $(\sim 2 \mu \mathrm{m})$ of the material. The fast neutron doses and fission fragment doses per hour were $\sim 2 \times 10^{16} \mathrm{n} / \mathrm{cm}^{2}$, and $\sim 1.5 \times 10^{15}$ fissions $\cdot \mathrm{cm}^{-3}$. The unirradiated ceramic consisted of spinel, hematite, plagioclase, and $(\mathrm{Na}, \mathrm{Ca}) \mathrm{U}_{2} \mathrm{O}_{7}$ as far as $\mathrm{X}$-ray diffraction was concerned. The uranate phase was rendered amorphous after a 1-hour 
irradiation, and the spinel and plagioclase phases became nearly amorphous after 10 hour irradiation; the hematite phase was unaffected. However, as mentioned earlier, fission fragment irradiation has dubious value as a simulation of $\alpha$-recoil effects. 


\subsection{LIKELY RADIATION EFFECTS ON SOLIDIFIED NUCLEAR WASTE FORMS}

The radiation doses of $\sim 10^{20} \alpha \cdot \mathrm{cm}^{-3}+\cdots 10^{13}-10^{14}$ fissions $\cdot \mathrm{cm}^{-3}+\beta^{-}$and $\gamma$-irradiation experienced in a solidified commercial HLW after $10^{6}$ years would certainly have undesirable effects on a poorly designed crystalline waste form. For instance, such a dose would render zircon amorphous and increase its specific volume by $\sim 16 \%$ (see. References 14,21 ; for example). Here we view the reduction of radiation effects in solidified commercial HLW as a design problem in which the goa 1 is to ensure that substantially all the $\alpha$ - and fission-fragment emitters are concentrated in radiation-insensitive phases.

The most radiation-insensitive phase known presently is almost certainly the fluorite-structured $(U, \operatorname{Ln}, A n) O_{2 \pm x}$. This material is known to be structurally resistant to the above radiation doses, $(12,39)$ with a lattice expansion of $\leqslant 1 \%$, and its leaching behavior appears to be satisfactory and insensitive to $\alpha$-damage, (40) as long as reducing conditions are maintained. (Reducing conditions are desirable for many other elements in radwaste also, such as Tc, Ru, Mo, etc.). Monazite, though it displays unexpected sensitivity to fission fragment irradiation, (37) should also be quite resistant to the above radiation dose. $(41,42)$

Thus, from the point of view of radiation sensitivity, the ceramic formulations of McCarthy $(7,34,35)$ in which monazite replaces the radiation-sensitive apatite ${ }^{(28)}$ should be eminently satisfactory. The titanate-ceramics $($ Synroc) $(43,44)$ seem less satisfactory notwithstanding the deliberately low (10\%) waste loading factor. Though the radiation doses would be somewhat lower than the above, in $10^{6}$ years of self-irradiation the perovskite and zirconolite phases, which for $\alpha$-recoil radiation appear to be approximately as sensitive as zircon, $(42,45,46)$ will be well on the way to being amorphous. ${ }^{(44)}$ Although it has been argued that amorphism, per se, will not disastrously decrease leach resistance, there have been counter-arguments in this regard. (23) Experimental data obtained in the laboratory on this question are still virtually non-existent, so judgment cannot really be made at this time. 
However, it seems that differential expansion effects will be large, bearing in mind that in titanate ceramics $(43,44)$ the hollandite phase (not an a-emitter host) will be substantially unaffected, if near-amorphism of the perovskite and zirconolite leads to a density decrease (and therefore volume expansion) comparable to that attendant $(20,45,57)$ upon the amorphization of zircon $(\sim 16 \%)$, quartz $(\sim 14 \%)$, or diamond $(\sim 45 \%)$. Somewhat unexpected7y, however, in a neutron-irradiated synthetic multiphase preparation ("Synroc B") in which the hollandite, perovskite, and zirconolite was irradiated, there was virtually no microcracking, while in single phase hollandite and perovskite preparations irradiated to the same dose (equivalent to $\sim 10^{4}$ years of expọsure) cracking, was fairly extensive. (48)

These examples, however, are only for particular ceramic formulations. The main point is that it should be possible by proper design, to make ceramic (or glass) formulations for commercial HLW in which the radiation damage problemis are only second-order effects. Obviously, if the commercial HLW is aged before solidification, radiation effects can be further reduced (see Table 4). 


\subsection{RADIATION SIMULATION METHODS FOR SOLID WASTE FORMS}

The various ways of producing radiation damage in solids have been mentioned. We have seen that solid HLW forms will experience a variety of radiation effects. As mentioned previously, although calculations ${ }^{(5)}$ indicated that the density of atomic displacements produced by $\alpha$-decay in waste forms would exceed that produced by fission fragment irradiation by about four orders of magnitude, these calculations neglect self-annealing and ionization effects in the fission fragment case. Indeed it seems likely from recent work ${ }^{(37)}$ that for some phases, fission fragment irradiation effects would be at least comparable to $\alpha$-recoil effects (e.g., monazite); other phases, not containing $\alpha$-emitting or fissionable ions, would receive fission fragment doses from adjacent phases (containing fissionable ions) but virtually no $\alpha$-recoil dose (e:g., hollandite); in yet others, the $\alpha$-recoil effects would dominate the fission phenomena $\left(\mathrm{UO}_{2+x}\right)$. In some cases, $\alpha$-particle damage might be more important than $\alpha$-recoil damage. $\left(\mathrm{UO}_{2+x} ;\right.$ Reference 39$)$.

For structural studies, it is suggested that wastes should be doped with $\alpha$-emitters. If further experiments suggest that solid-phase radiolysis effects ${ }^{\text {(15- }}$ 17) are significant, then extended ${ }^{60}$ Co $\gamma$-irradiations could be employed; doses in the order of $10^{12} \mathrm{R}$ are required, however. (4)

For (radiation effects on) leaching studies, however, if the specific radioactivity of the sample is much higher than that of the form simulated (to produce adequate structural damage) then leaching effects produced by radiolysis of the solvent by the sample will be greatly exaggerated. Here it is suggested that structural damage be produced by a means that leaves the sample only minimally radioactive (by "external" irradiation). 


\subsection{TRANSMUTATION EFFECTS}

Table 2 shows the fission products derived from U-based reactor fuel, and Table 6 shows the key elements for which transmutation problems will arise when the nuclides are solidified. The transmutation problem in a solid waste form derives from the fact that when a nuclide undergoes radioactive decay, the newlyformed atom may be a chemically different species, having a different ionic size and, possibly, valence. Thus, if the nuclide is chemically incorporated in a solid form before transmutation, it may not fit into the lattice after transmutation has occurred.

\section{TABLE 6}

RELATIVELY ABUNDANT FISSION PRODUCT ELEMENTS

FOR WHICH A VALENCE CHANGE WILL OCCUR IN A SOLID WASTE FORM AND WHICH HAVE $t_{1 / 2}<10^{5}$ YEARS

\begin{tabular}{c|c|c}
\hline Element & $\begin{array}{c}\text { Stable } \\
\text { Daughter }\end{array}$ & $t_{1 / 2}$ (year) \\
\hline $\mathrm{Cs}$ & $\mathrm{Ba}$ & 30 \\
$\mathrm{Sr}$ & $\mathrm{Zr}$ & 29 \\
$\mathrm{Kr} *$ & $\mathrm{Rb}$ & 11 \\
\hline
\end{tabular}

* Will not exist in general waste stream

In typical nuclear reprocessing wastes, the most significant transmutations are ${ }_{55}^{137} \mathrm{Cs}+\mathrm{B}^{-}{ }_{56}^{137} \mathrm{Ba}^{2+}\left(t_{1 / 2}=30\right.$ years $)$ and ${ }_{38}^{90} \mathrm{Sr}^{2+} \stackrel{\beta^{-}}{\longrightarrow}{ }_{39}^{90} \gamma^{3+}\left(t_{1 / 2}=29\right.$ years $)$ $\stackrel{B^{-}}{9} 40 \mathrm{Zr}^{4+}\left(\mathrm{t}_{1 / 2}=64 \mathrm{~h}\right)$. For the latter decay series, the amount of $\mathrm{Y}^{3+}$ relative to $2 r^{4+}$ is negligible:

In both the $\mathrm{Cs}^{+} \rightarrow \mathrm{Ba}^{2+}$ and $\mathrm{Sr}^{2+} \rightarrow \mathrm{Zr}^{4+}$ transmutations the ionic size differences are $20-40 \%$. This alone poses problems, but there are several structures in which the ionic radius tolerance factor is substantial; for example, the XII-fold site in perovskite has been known for many years to tolerate a $40 \%$ size change. 
A. mechanism for charge compensation is another matter, and both crystalline and non-crystalline phases (insulators) share the same problem which must be resolved by corresponding changes in other cations or anions. (No transmutation problem due to valence changes occurs in a metal; "electrical neutrality" does not apply. However, a metai containing appreciable Cs or Sr would be very reactive with water.) For insulating crystals it seems clear that some proportion $(\approx 1 \%)$ of transmutation could be accommodated but that disproportionation or "decomposition" would take place after a certain proportion of the ions had become transmuted. If this process took place at a sufficiently low temperature (preventing appreciable atomic diffusion) the lattice strains around the transmuted (now misfitting) ions would cause smearing-out of the X-ray diffraction pattern much in the same way as does radiation damage cold-work or glass formation. The transmutation-induced departure from thermodynamic equilibrium would increase as transmutation continued, and it would be a question of kinetics when phase decomposition would occur.

Two lines of experimentation are possible to study the possible effects of transmutation on solid waste forms. These are: (1) fundamental transmutation studies using radioactive or neutron-induced transmutation, and (2) chemica? studies of phase stabilities when transmutation is simulated, with emphasis for the problem of nuclear waste disposal on mitigation of phase disproportionation or decomposition.

\subsection{FUNDAMENTAL TRANSMUTATION STUDIES}

Virtually no relevant studies have actually been performed, though one ${ }^{(49)}$ is in progress. To study transmutation effects on the structures of crystais, diffraction studies are vital. Although isolated (transmuted) cation studies in solids can be made with techniques such as $\gamma$ angular correlation, Mössbauer, optical, and paramagnetic resonance spectroscopies, this information does not directly relate to the "collective" state of the solid and its phase constitution. Ten percent of transmutation of a major element in the phase of interest should be sought as a minimum in fundamental studies. In such studies, both radioactive and 
neutron-induced transmutation would seem worth pursuing. The advantages of (reactor) neutron-induced transmutation are that the desired sample can be prepared using stable isotopes so that there are no constraints on sample preparation, either in terms of material volume or of preparation time. The disadvantages are the long irradiation times required to produce an adequate degree of transmutation and possible radiation damage complications from fast neutron fluxes.

Other considerations are as follows:

1) Parent and daughter must not be variable-valence transition metals or actinides (see below);

2) After neutron capture, transmutation must take place in a reasonable time and via $\beta^{-}, \beta^{+}$, or electron-capture, not by fission or evolution of massive particles which would introduce additional radiation damage;

3) No other nuclei, including the daughter of the compound nucleus, must undergo any significant transmutation.

Even with quite a high thermal neutron flux, say $10^{14} \mathrm{n} / \mathrm{cm}^{2} \cdot \mathrm{s}$, for $10 \%$ transmutation the product of the isotope abundance and the particular absorption crosssection must exceed 30 barns, if irradiation times are not to exceed one year.

The mos.t favorable cases appear to be ${ }_{55}^{133} \mathrm{Cs}^{+}+{ }^{\mathrm{n}^{1}} \rightarrow{ }_{55}^{134} \mathrm{Cs}^{+} \stackrel{B^{-}}{\longrightarrow}$ ${ }_{56}^{134} \mathrm{Ba}^{2+}$ and ${ }_{72}^{174} \mathrm{Hf}^{4+}+\mathrm{O}^{\mathrm{n}^{1}} \rightarrow{ }_{72}^{175} \mathrm{Hf}^{4+} \stackrel{\varepsilon}{ }{ }_{71}{ }_{71} \mathrm{Lu}^{3+}$. However, the induced radioactivities would be formidable for $\sim 10 \%$ transmutation, the specific activities of possible host compounds being on the order of $100 \mathrm{Ci} / \mathrm{gm}$ on withdrawal from the reactor and the principal half-lives being 2.0 and 0.2 years, respectively, for the two cases above.

These levels of activity will surely tax X-ray diffraction apparatus, even with large amounts of shielding to reduce the radioactive background. Electron diffraction would be a preferred technique, especialiy as the absolute activity of an electron diffraction sample would be quite low (for general discussions of problems of diffraction on radioactive samples (see References 50 and 51). 


\subsection{CHEMICAL MITIGATION STUDIES}

Here the approach is to select multiple-cation solids for transmutation resistance, the idea being to select structures which can accommodate parent and daughter in the same site and which contain cations which can change valence to compensate for the transmutation-induced valence change.

For example, with the $\mathrm{Cs}^{+} \rightarrow \mathrm{Ba}^{2+}$ transmutation we would seek a mineral phase solid solution of the type

$$
\mathrm{Cs}^{+} \mathrm{R}^{\mathrm{z}} 0_{(\mathrm{z}+1) / 2} \rightarrow \mathrm{Ba}^{2+} \mathrm{R}(\mathrm{z}-1)+{ }^{+}{ }_{(z+1) / 2}
$$

This approach to mitigation of the transmutation problem has been explored in some detai1. (52). Though simple in concept, it has not been found very easy to apply the strategy; so far, perovskite looks promising to deal with the $\mathrm{Cs} \rightarrow \mathrm{Ba}$ transmutation, but no system for the $\mathrm{Sr}^{2+} \rightarrow \mathrm{Zr}^{4+}$ transmutation has been found. Other possible solid phase hosts have also been discussed and it was also pointed out that the transmutation problem will not disappear in an amorphous waste form. (52)

\subsection{THE TRANSMUTATION PROBLEM. IN SPECIFIC RADWASTE FORMULATIONS}

Dilution is an obvious means of easing the transmutation problem. Defense . wastes are already very dilute in radionuclides so no important problems of phase instabilities due to transmutation are anticipated. However, formulations for reprocessing waste could have difficulties. The Ringwood $(43,44)$ formulation is designed to be a dilute solution of radwaste in three major phases, Ba-hollandite, zirconolite, and perovskite, so further dilution of the radwaste by the $\mathrm{Ba}, \mathrm{Ca}$, $\mathrm{Zr}, \mathrm{Al}$, and Ti oxides composing the "solvent" could be achieved. Within limits, also, the mixture could be diluted by just the problem elements, viz., Cs and Sr.

On the other hand, the McCarthy $(7,34,35)$ formulations were found in the present work not to be amenable to dilution by the tailoring additives, $\mathrm{Ca}, \mathrm{Sr}$, $A 1$, and $\mathrm{Si}$ oxides insofar as additions of any combinations of excess $\mathrm{Al}_{2} \mathrm{O}_{3}$ and 
$\mathrm{SiO}_{2}$ (added as $\mathrm{SiO}_{2}$ sol and aluminum nitrate solution to the starting mixture) upset the phase assembiage. Nor could the formulation tolerate dilution with pollucite (again added in the form of stoichiometric mixtures of Cs, Al, and $\mathrm{Si}$ oxides via $\mathrm{SiO}_{2} \mathrm{sol}$ and metal nitrate solutions). In both cases, the pollucite and scheelite phases (for Cs and Sr,Mo, respectively) were "lost," as far as X-ray diffraction was concerned. For $\mathrm{Al}_{2} \mathrm{O}_{3}$ and $\mathrm{SiO}_{2}$ additives, some extra $X$-ray reflections were observed but for the "pollucite" addition, there were no extra reflections observed. No great increase in Cs volatility was observed on firing, both from gravimetric work and from the observations that, on firing at 1100 or $1200^{\circ} \mathrm{C}$, the $X$-ray diffraction patterns of air-fired materials were very similar to those of materials fired in welded platinum capsules. 


\subsection{CONCL.USIONS AND FINAL REMARKS}

In the light of existing data on refractory phases, radiation and transmutation effects should have little significance in ceramic forms for defense wastes, because of the high degree of dilution of the critical radioactive ions in these wastes.

For reprocessing wastes, the more dilute and the older the waste, the less will be the problems with radiation and transmutation, but for radiation at least there appear to be crystalline materials such as monazite and uraninite which are quite radiation-resistant. Here the design problem is to ensure all the $\alpha$-emitters enter the uraninite and/or monazite phases. However, the possibilities that B-emission could cause appreciable radiation damage need examination.

For Cs- and Sr-bearing phases in reprocessing wastes it will not be easy to design for transmutation resistance in conjunction with thermal stability, leach resistance. However, the chemical mitigation approach ${ }^{(52)}$ might apply in a metastable sense if transition metal ions are present in the Cs- and Sr-containing phases. Even if future work produces appropriate transmutation-resistant phases for Cs and Sr individually, this would produce of itself little stimulus for partitioning nuclear waste streams unless the regulatory situation necessitates transport of wastes.

The main driving force for partitioning $\mathrm{Cs}$ and $\mathrm{Sr}$ from reprocessing wastes is that the ${ }^{137} \mathrm{Cs}$ and ${ }^{90} \mathrm{Sr}$ can be made up into quite soluble forms such as ${ }^{137} \mathrm{CsCl}$ and ${ }^{90} \mathrm{SrF}_{2}$ (and leaving a Na-rich solution which can be evaporated to dryness, leaving an essentially nonradioactive salt cake), as is done for the defense wastes at the Hanford site; these materials need only be encapsulated onsite in an appropriate container for $\sim 500$ years, since at the end of this period, the ${ }^{137} \mathrm{Cs}$ and ${ }^{90} \mathrm{Sr}$ have virtually completely decayed to stable elements. The remaining fission products and actinides from the original (aged) waste streams will have minimal $\gamma$-heat production so the appropriate waste form should be correspondingly easier to design. Nevertheless, this would add considerably to the cost of the operation. 


\section{REFERENCES}

1. N. H. Macmillan, R. Roy, and P. T. B. Shaffer, "Metal Matrix Radioactive Waste Forms Prepared by Electrochemical/Gravity Deposition," Nucl. Tech., in press (1980)

2. D. W. Kneff, "Radiation Effects Simulation in High Level Nuclear Waste Forms: A Literature Review," Supporting Document No. 364TI00001, Energy Systems Group, Rockwe11 International, Canoga Park (1980)

3. H. M. Lee, "Natural Radiation Damage in Solids: A Literature Review," Supporting Document No. 264TI00002, Energy Systems Group, Rockwe 11 International (1980)

4. P. H. Permar and W. R. McDonell, "Significance of Radiation Effects in Solid Radioactive Waste," DP-MS-80-27, ASTM Proceedings Tenth Symposium of Radiation on Materials, in press (1980)

5. F. P. Roberts, G. H. Jenks, and C. D. Bopp, "Radiation Effects in Solidified High-Level Wastes -- Part I," Stored Energy, USERDA Report BNWL-1944, Battelle Pacific Northwest Laboratories, Richland, Washington (1976)

6. G. Malow and H. Andresen, "Helium Formation from a-Decay and its Significance for Radioactive Waste Glasses," in Scientific Basis for Nuclear Waste Management, Vol. I, Ed. G. J. McCarthy (P Tenum, New York), 109

7. G. J. McCarthy and M. T. Davidson, "Ceramic Nuclear Waste Forms: I, Crystal Chemistry and Phase Formation," Bu11. Amer. Ceram. Soc. 54, 782 (1975)

8. C. M. Lederer, J. M. Hollander, I. Pearlman, and V. S. Shirley, Table of Isotopes, 7th.Edition, John Wiley (197.9)

9. G. H. Kinchin and R. S. Pease, "The Displacement of Atoms in Solids by Radiation," Repts. Prog. Phys. 18, 1 (1955)

10. M. Antonini, F. Lanza, and A. Manara, "Simulations of Radiation Damage in Glasses," Ceramics in Nuclear. Waste Management, DOE Publication, CONF-790420, 289 (1979)

11. R. M. Berman, M. L. Bleiberg, and W. Yeniscavish, "Fission Fragment Damage to Crystal Structures," J. Nucl. Mat. 2, 129 (1960)

12.. M. C. Wittels, J. 0. Steigler, and F. A. Sherrill, "Radiation Effects in Uranium-Doped Zirconia, Reactor Science and Technology," J. Nucl. Energy, Pts. A/B) 16, 237

13. E. R. Vance and J. N. Boland, "Fission Fragment Damage in Zircon," Radiation Effects 26, 135 (1975) 
14. E. R. Vance and J. N. Boland, "Fission Fragment Irradiation of Single Crystal Monoclinic $\mathrm{ZrO}_{2}$," Radiation Effects 37, 237 (1978)

15. L. W. Hobbs, "Application of Transmission Electron Microscopy to Radiation Damage in Ceramics," J. Amer. Ceram. Soc. 62, 267 (1979.)

16. M. R. Pascucci and L. W. Hobbs, "Metamict Transformation in Silicate-Based Waste-Storage Media," Bu11. Amer. Ceram. Soc. 59, 395 (1980)

17. L. W. Hobbs and M. R. Pascucci, "Radiolysis and Defect Structure in ElectronIrradiated $\alpha$-Quartz, J. Phys. Paris $\underline{\mathrm{C} 6}, 237$ (1980)

18. W. Primak, "Notes on Radiation Effects in Glasses Pertinent to Solid Storage of Radioactive Wastes," In Ceramic and Glass Radioactive Waste Forms," D. W. Readey and C. R. Cooley, Eds., Energy Research and DeveTopment Admin. Workshop Publication CONF-770102, pp. 157-176

19. W. Primak, The Compacted States of Vitreous Silica, Gordon and Breach, New York (1975)

20. D. S. Billington and J. H. Crawford, Jr., Radiation Damage in Solids, Princeton U.P., 233 (1961)

21. A. Pabst, "The Metamict State," Amer. Minera1. 37, 137 (1952)

22. R. S. Mitche11, "Metamict. Minerals: A Review," Min. Record 4, 177, 214 (1973)

23. R. F. Haaker and R. C. Ewing, "The Metamict State Radiation Damage in Crystalline Materials," Ceramics in Nuclear Waste Management, DOE Publication, CONF-790420, 305 (19.79)

24. H. M. Naguib and R. Kelly, "Criteria for Bombardment-Induced Structural Changes in Non-Metallic Solids," Radiation Effects 25, 1. (1975)

25. F. A. Mumpton and R. Roy, "Hydrothermal Stability Studies of the ZirconThorite Group,". Geochim. Cosmochim. Acta 21, 217 (1961)

26. T. Takamori and R. Roy, "Crystallization Temperature - A New Parameter to Characterize Noncrystalline Oxide Materials," in Advances in Nucleation and Crystallization of Glasses, Eds. L. L. Hench and S. W. Freiman, American Ceramic Society, Columbus, Ohio, 173 (1971)

27. W. J. Weber, R. P. Turcotte, C. R. Bunnell, F. P. Roberts, and J. H. Westsik, Jr., "Radiation Effects in Vitreous and Devitrified Simulated Waste Glass," Ceramics in Nuclear Waste Management, DOE, CONF-790420, 294 (1979)

28. W. A. Ross, R. P. Turcotte, J. E. Mendel, and J. E. Rusin, "A Comparison of Glass and Crystalline Waste Materials," ibid., 52 (1979) 
29. M. J. Mendelssohn, PhD Thesis, University of London, unpublished (1971)

30. E. C. H. Silk and R. S. Barnes, "Examination of Fission Fragments Tracks with an Electron Microscope," P.hil. Mag. 4, 970 (1959)

31. R. L. Fleischer, "Isotope Disequilibrium of Uranium: Alpha-Recoil Damage and Preferential Solution Effects," Science 207, 979 (1980)

32. R. L. Fleischer and P. B. Price, "Charge-Particle Tracks in Glass," J. Appl. Phys. 34, 2903 (1963)

33. K. D. B. Johnson, "The U.K. Program -- Glasses and Ceramics for Immobilization of Radioactive Wastes for Disposal," ibid., 17 (1979)

34. G. J. McCarthy, "High-Level Waste Ceramics," Trans. Amer. Nucl. Soc. 23, 168 (1976)

35. G. J. McCarthy, "High-Level Waste Ceramics: Materials Considerations, Process Simulation, and Product Characterization," Nucl. Tech. 32, 92 (1977)

36. J. M. Rusin, R. 0. Lokken, and J. W. Wald, "Alternative Waste Forms -- A Comparative Study," Scientific Basis for Nuclear Waste Management, Vol. 1, G. J. McCarthy (Ed.), Plenum Press, New York, p. 169 (1979)

37. E. R. Vance and K. K. S. Pillay, "Experimental Study of Structural Damage from Fission Fragment Irradiation in Crystalline Nuclear Waste Phases," presented at the Materials Research Society meeting in Boston, Massachusetts (November 1980)

38. N. E. Bibler and J. A. Kelley, "Effect of Internal Alpha Radiation ion Borosilicate Glass Containing Simulated Radioactive Waste," USAEC Report DP-MS-75-94, Savannah River Laboratory, E.I. DuPont deNemours Co., Aiken, South Carolina (1976)

39. W. J. Weber, "Ingrowth of Lattice Defects in Alpha-Irradiated $\mathrm{UO}_{2}$ Single Crystals," PNL-SA-8574 (1980)

40. D. E. Grandstaff, "A Kinetic Study of the "Dissolution of Uraninite," Econ. Geol. 71,1493 (1976)

41. G. J. McCarthy, W. B. White, and D. E. Pfoertsch, "Synthesis of Nuclear Waste Monazites, Ideal Actinide Hosts for Geologic Disposa1," Mat. Res. Bu11. 13, 1239 (1978)

42. Generic Environmental Impact Statement. Management of Commercially Generated Radioactive Waste: Appendix P, U.S. Department of Energy, D0E/E15-0046-D (1979)

43. A. E. Ringwood, S. E. Kesson, N. G. Ware, W. Hibberson, and A. Major "Immobi 1ization of High-Level Nuclear Reactor Wastes in SYNROC," Nature 278, 219 (1979) 
44. A. E. Ringwood, S. E. Kesson, N. G. Ware, W. O. Hibberson, and A. Major, "The SYNROC Process: A Geochemical Approach to Nuclear Waste Immobilization," Geochem. Journa T (Japan). 13, 144 (1979)

45. H. D. Holland and:D. Gottfried, "The Effect of Nuclear Radiation on the Structure of Zircon," Acta Cryst. $\underline{8}, 291$ (1955)

46. A. E. Ringwood, V. Oversby, and W. Sinclair; "Effects of Radiation Damage in Long-Term Stability of SYNROC Minerals," Scientific Basis for Nuclear Waste Management, Vol. 2, C. J. Northrup (Ed.), Plenum Press, New York, p. 273 (1980)

47. E. R. Vance, "X-ray Study of Neutron-Irradiated Diamond," J. Phys. C: Solid St. Phys. 4 , 257 (1971)

48. K. D. Reeve and J. L. Woolfrey, "Accelerated Irradiation Testing of SYNROC Using Fast Neutrons," I: First Results on Barium Hollandite, Perovskite and Undoped SYNROC B, J. Aust. Ceram. Soc. 16, in press (1980)

49. W. J. Weber, J. W. Wald, and W. J. Gray, "Radiation Effects in Crystalline High-Level Nuclear Waste Solids, PNL-SA-8732 (1980)

50. D. Schiferl and R. B. Roof, "X-ray Diffraction of Radioactive Materials," Advances in X-ray Analysis, Vol. 22, G. J. McCarthy, C. S. Barrett, D. E. Leyden, J. B. Newkirk, and C. 0. Ruud (Eds.), Plenum, New York, p. 31 (1978)

51. R. G. Haire and J. R. Peterson, "X-ray Powder Diffraction of Einsteinium Compounds.," ibid., p. 101 (1978)

52. E. R. Vance, R. Roy, J. G. Pepin, and D. K. Agrawal, "Chemical Mitigation of the Transmutation Problem in Crystalline Nuclear Waste Radiophases," in preparation 
DEVELOPMENT OF TAILORED CERAMICS

FOR

GEOLOGIC STORAGE OF NUCLEAR WASTES

QUARTERLY PROGRESS REPORT

OCTOBER 1, 1979 THROUGH DECEMBER 31, 1979

\author{
PREPARED FOR THE U.S. DEPARTMENT OF ENERGY \\ SAVANNAH RIVER OPERATIONS OFFICE \\ UNDER CONTRACT \\ DE-AC09-79ET 41900
}

BY

ROCKWELL INTERNATIONAL CORPORATION

Energy Systems Group

8900 De Soto Avenue

Canoga Park, California 91304

February 15,1980

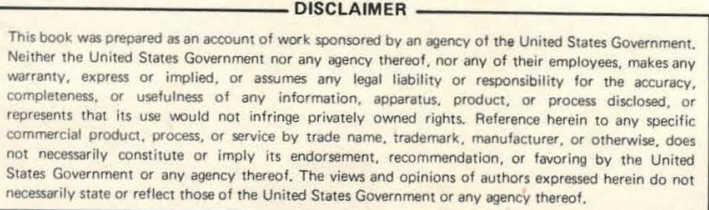

This report contains information of a preliminary nature prepared in the course of work for the United States Government. Since it is transmitted in advance of patent clearance, it is made available in confidence solely for use in performance of work under contracts with the U. S. Government. This document is not to be published nor its contents otherwise disseminated or used for purposes other than specified above before patent approval for such release or use has been secured, upon request, from the cognizant Government Patent Counsel. 
5

(n)

QS

$-5$

xis deres 
CONTENTS

Page

1.0 PROJECT DESCRIPTION AND OBJECTIVES................ I

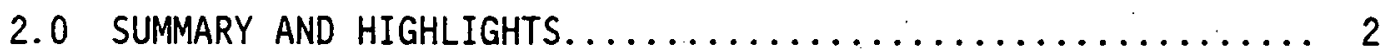

2.1 Tailored Ceramic Waste Form Development and

Characterization............................ 2

2.2 Tailored Ceramic Process and Equipment Development.... 2

3.0 TECHNICAL PROGRESS ............................ 4

3.1 Tailored Ceramic Waste Form Development and

Characterization........................... 4

3.1.1 Generic and Fundamental Studies.......... 4

3.1.2 Formulation and Consolidation Studies......... 16

3.1.3 Radiation and Transmutation Effects........... 19

3.1.4 Geologic Strata Compatibility...............21

3.2 Tailored Ceramic Process and Equipment Development.... 21

3.2.1 Engineered Containment.................. 21

3.2.2 Process Evaluation and Definition........... 21 


\subsection{PROJECT DESCRIPTION AND OBJECTIVES}

A multitask program is being carried out for the development and characterization of Tailored Ceramics as a waste form for the geologic storage of radioactive wastes. The feasibility of producing the waste form safely and reliably under large-scale remote operating conditions is being assessed, and the long-term stability of the ceramic form is being evaluated vis-a-vis borosilicate glass.

Tailored Ceramics are crystalline assemblages made by high-temperature and pressure consolidation of a nuclear waste with selected additives. The specific crystalline phase assemblages produced by the waste tailoring process closely approximate those found in natural minerals which have persisted for geologic ages. These consolidated ceramic forms provide a total volume reduction for the waste and are extremely hard, dense materials with low surface areas and potential for high leach resistance.

The program involves basic studies at the Pennsylvania State University's Materials Research Laboratory, applied research at Rockwe 11 International's Science Center, process and remote fabrication technology development at Rockwell International's Energy Systems Group, and engineering deveiopment support at Rockwell's Hanford Operations. This integrated effort is directed toward advancing Tailored Ceramic technology to the state where it provides a viable alternative waste form for use at the SRP and other installations: 


\subsection{SUMMARY AND HIGHLIGHTS}

\subsection{TAILORED CERAMIC WASTE FORM DEVELOPMENT AND CHARACTERIZATION}

Generic and Fundamental Studies (Task 2) are underway on (1) crystalline phases for Savannah River Plant (SRP) sludges, and phases for iodine and fluoride fixation, (2) cement matrices for Tailored Ceramic phases, (3) mechanism and kinetics of dissolution of pollucite, Sr-feldspar, and nepheline, and (4) fundamental transmutation effects. Simulated SRP sludge yielded spinel and, depending on additives, $\alpha-\mathrm{Al}_{2} \mathrm{O}_{3}$, $\mathrm{UO}_{2}$, cristobalite, and mullite. Nd monazite appears to be compatible with a variety of high silica and high alumina cements. CsFeSi ${ }_{2} \mathrm{O}_{6}$ appears promising as resistant to the ${ }^{137} \mathrm{Cs}$ to ${ }^{137} \mathrm{Ba}$ transmutation.

Formulation and Consolidation Studies (Task 3 ) have established an initial tailoring formula based on alumina, yielding a four-phase crystalline assemblage: corundum, spinel, magnetoplumbite, and uraninite. Hard, dense hot-pressed ceramic pellets have been prepared in the laboratory, and host phase identification for various species of concern is underway.

The initial Radiation and Transmutation Effects (Task 4) effort has included the establishment of a program plan and key contacts with other researchers in the field, the initiation of a detailed literature review of the radiation damage field as applied to nuclear waste forms, and a start on formulating the program's first radiation damage experiments. Task 5 Geologic Strata Compatibility stuides had not been initiated during the quarter.

\subsection{TAILORED CERAMIC PROCESS AND EQUIPMENT DEVELOPMENT}

Under Engineered Containment (Task 6), current technology is under review and assessment, and a report library has been established. 
Under Process Evaluation and Definition (Task 7); the unit operations needed to carry out steps in the Tailored Ceramic process are under evaluation. Hot pressing, hot isostatic presising, and calcination are the operations of immediate interest in conjunction with the processing concept in which the alumina in the waste is retained to serve as a tailoring ingredient in forming a consolidated Tailored Ceramic waste form. 


\subsection{TECHNICAL PROGRESS}

\subsection{TAILORED CERAMIC WASTE FORM DEVELOPMENT AND CHARACTERIZATION}

\subsubsection{Generic and Fundamental Studies}

Task 2, "Generic and Fundamental Studies," is devoted to the development and characterization of new materials capable of either containing the desired radionuclide as an essential part of the crystal structure (the high-loading option) or taking some quantity of the radionuclide into stable solid solution (the low-loading option).

\subsubsection{Optimum Phases for Tailored Ceramics}

This aspect of the work is with the crystalline phases that can be formed from a Savannah River Plant (SRP) sludge and with new crystalline waste forms specifically designed for the radionuclides in other highlevel wastes.

Work has been started on phases for strontium, cesium, iodine, and rare earth elements. In each case, the approach is to first identify crystalline hosts that will accept the radionuclide(s) in question, then address questions of thermal stability during synthesis and processing, and then investigate mutual compatibility of phases that must coexist in the final ceramic product.

\subsection{Crystalline Phases from Fired Simulated Savannah River Sludge}

Since these materials are rich in aluminum and iron, there appears to be a very good possibility of forming ceramics directiy by firing the sludge. Ceramic bodies were made by drying solutions or slurries at $-120^{\circ} \mathrm{C}$, calcination at $600^{\circ} \mathrm{C}$, grinding, pelletizing using a pressure of $-3 \times 10^{4} \mathrm{psi}$, and firing at $900-1200^{\circ} \mathrm{C}$. On firing a simulated sludge 
at $900-1200^{\circ} \mathrm{C}$, a spinel of undetermined constitution was the dominant phase, but many other unidentified X-ray lines were observed.

Use of silica, alone and with other additives, was then studied for tailoring of the SRP sludge. A mixture of nitrate solutions (of cation composition similar to the previous simulation) plus Ludox (colloidal $\mathrm{SiO}_{2}$ ) was made. $\mathrm{X}$-ray data similar to those for the additive-free simulation were obtained with ceramics fired at $1000-1200^{\circ} \mathrm{C}$.

The effect of fairly large quantities of tailored additions to the nitrate-based simulation was studied, the additions being ( 1 ) 60 mole $\%$

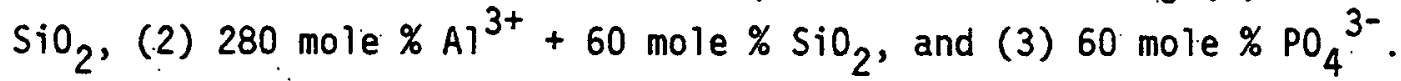
The $\mathrm{SiO}_{2}$ and $\mathrm{H}_{3} \mathrm{PO}_{4}$ additions ( 1 and 3 above) produced melting on subsequent firing at $1200^{\circ} \mathrm{C}$. The mechanical properties of pellets made with all of these additives were poor, while those of the addition-free material seemed satisfactory.

Addition of sodium, a potentially damaging additive from a leaching standpoint, was explored, as was that of calcium. The additions to the nitrate-base simulation were (1) $60 \mathrm{~mole} \% \mathrm{Na}^{+}$, (2) $60 \mathrm{~mole} \% \mathrm{Ca}^{2+}$, and (3) 60 mole $\% \mathrm{Na}^{+}+60$ mole $\% \mathrm{Ca}^{2+}$. As found by McCarthy for commercial wastes, sodium additions improved the mechanical properties. Calcium addition produced somewhat less of an improvement, but the addition (3) produced a poorly crystallized and mechanically weak "ceramic" even on firing at $1200^{\circ} \mathrm{C}$. Spinel was a dominant phase in (1) and (2) but was absent in (3). No nepheline or sodium silicate phases were observed.

A second nitrate + Ludox mixture was made up with enhanced uranium and strontium concentrations to try to clarify the phases bearing these elements. The hydroxides were precipitated with excess $\mathrm{NH}_{4} \mathrm{OH}$ and then calcined and fired as usual. The effect of 10 mole \% additions of calcium or aluminum was trivial as far as $X$-ray diffraction was concerned, but the addition of 10 mole $\% \mathrm{SiO}_{2}$ was to promote the formation of $\mathrm{UO}_{2+x}$ as against a presumed uranate phase. 
Spinel was observed in most cases. $\mathrm{High}_{\mathrm{SiO}}$ led to an amorphous phase and cristobalite formation. High $A 1$ led to $\alpha-\mathrm{Al}_{2} \mathrm{O}_{3}$ formation, while high Al plus $S i$ led to formation of $\mathrm{Al}_{6} \mathrm{Si}_{2} \mathrm{O}_{13}$ (mullite). With high $\mathrm{PO}_{4}^{-3}$ additions, no phase identifications were obtained.

The spinel was not noticeably suppressed by (so is, therefore, presumably compatible with) $\mathrm{Al}_{2} \mathrm{O}_{3}$ and $\mathrm{SiO}_{2}$ additions. Moreover, as there was a large fraction of unreacted (albeit crystallized) $\mathrm{Al}_{2} \mathrm{O}_{3}$ and $\mathrm{SiO}_{2}$, there appears to be no impediment to the formation of Sr-feldspar and pollucite to tie up ${ }^{90} \mathrm{Sr},{ }^{134} \mathrm{Cs}$, and ${ }^{137} \mathrm{Cs}$.

As expected, firing in a reducing atmosphere promoted the formation of the $\mathrm{UO}_{2+x}$ phase rather than $\mathrm{U}_{3} \mathrm{O}_{8}$ or the presumed uranate phase. However, the chemical details of why adding $\mathrm{SiO}_{2}$ to the second nitrate simulation promoted $\mathrm{UO}_{2+x}$ as against the uranate phase are not clear.

\subsection{Iodine Fixation}

A candidate crystalline host for ${ }^{129} \mathrm{I}$ is boracite. The mineral boracite is $\mathrm{Mg}_{3} \mathrm{~B}_{7} \mathrm{O}_{13} \mathrm{Cl}$. However, there are many isostructural compounds in which magnesium is replaced by other intermediate-size cations and chlorine is replaced by bromine or iodine. The halogen in the boracite structure is encapsulated within a three-dimensional framework of boronoxygen polyhedra, suggesting that this structure may be useful for immobilizing iodine. So far, synthesis of an iodine boracite has not been successful.

Fe-I-boracite crystals, grown elsewhere by chemical transport techniques, were unaffected by a $\gamma$-dose of $\sim 10^{9} R$, but decomposed on heating in air at $900^{\circ} \mathrm{C}, \alpha-\mathrm{Fe}_{2} \mathrm{O}_{3}$ being the major decomposition product detected by $X$-ray diffraction. Some evidence was obtained that $\mathrm{Fe}-\mathrm{I}-$ boracite is unstable on prolonged heating at $300^{\circ} \mathrm{C}$. If substantiated, this result severely jeopardizes $\mathrm{Fe}$-I-boracite as a candidate iodine 
fixer. Although jodine would be processed separately from the main nuclear waste, an iodine fixer would be buried. in the same repository as high-level waste, and thus it would experience near-field temperatures of $\geq 100^{\circ} \mathrm{C}$, even though. $\beta, \gamma$-heating in the iodine fixer itself would be negligible because of the long half life of ${ }^{129} \mathrm{I}$.

\subsection{Fluoride Fixation; Thorex Wastes}

McCarthy showed that fluoride-bearing phases could not be accommodated in "supercalcine" Tailored Ceramic phases based on PW-4b and PW- 7 high-level nuclear wastes. It was shown that $\mathrm{Ca}_{5}\left(\mathrm{PO}_{4}\right)_{3} \mathrm{~F}$ was thermally stable up to $-1000^{\circ} \mathrm{C}$, although chemical analysis showed the $\mathrm{F}$ content to be only about $50 \%$ of the theoretical value. After heating at $1200^{\circ} \mathrm{C}$, the $F$ content was oniy about $1.5 \%$ of the theoretical value, but the $X$-ray patterns were apparently virtually unchanged. In the present work, heating the fluorapatite phase at $1350^{\circ} \mathrm{C}$ caused complete decomposition to $\alpha-\mathrm{Ca}_{3}\left(\mathrm{PO}_{4}\right)_{2}$.

$\mathrm{Sr}_{2} \mathrm{FeO}_{3} \mathrm{~F}$ is reportediy stable at temperatures of up to $1200^{\circ} \mathrm{C}$. Well crystallized $\mathrm{Sr}_{2} \mathrm{FeO}_{3} \mathrm{~F}$ was produced by drying, calcination, and firing mixed nitrate and $\mathrm{NH}_{4} \mathrm{~F}$ solutions. A firing temperature of $-900^{\circ} \mathrm{C}$ seemed to be optimum, although phase-pure material was not obtained. However, heat treatment for 1 week at $1050^{\circ} \mathrm{C}$ produced complete decomposition into $\mathrm{SrFe}_{2} \mathrm{O}_{4}$ plus unknown phases.

\subsubsection{Tailored Ceramic Composites}

Commercial and modified cements are being considered as matrices or bases for ceramic waste forms. To test their suitability, samples were prepared for controlled curing and leaching experiments. Individual Tailored Ceramic waste form phases are being examined to delineate their behavior in cement matrices more precisely. An alumina based cement (Secar 71) and two silicate cements ( $C$ lass $C$ and Class $H$ ) were chosen. 
$\mathrm{NdPO}_{4}$ is a monazite structure compound (where neodymium is a model rare earth and a stand-in for the actinides) which is the first Tailored Ceramic phase being tested for compatibility in cement compounds. Samples were prepared with cement as-received and modified as follows:

1) $\mathrm{NdPO}_{4}$ plus $20 \mathrm{wt} \%$ of the cement

2) Compositionally adjusted with amorphous $\mathrm{SiO}_{2}$

3) Addition of $\mathrm{SiO}_{2}$ and $\mathrm{NdPO}_{4}$.

Addition of $\mathrm{SiO}_{2}$ was intended to approximate tobermorite for the silicate cements and feldspar $+\mathrm{Al}_{2} \mathrm{O}_{3}$ for the aluminate cement.

Each cement formulation was cast to permit sampling at intervals during isothermal curing $\left(60^{\circ} \mathrm{C}\right)$. Accelerated hydrothermal leach testing, and characterization of the solids by $X$-ray diffraction and SEM, were performed on samples taken after 28 and 56 days. Interpretation of the data from $X$-ray diffraction is underway.

Hydrothermal leaching was conducted for 28 days at $200^{\circ} \mathrm{C}$ and $30.4 \mathrm{MPa}$ overpressure on subsamples of approximately $0.05 \mathrm{gm}$ (total solids) sealed in noble metal tubes with $0.5 \mathrm{gm}$ deionized water. Solutions were analyzed by atomic emission. Solids remaining after leaching were studied by $X$-ray diffraction and scanning electron microscopy. Refinement of these studies is continuing.

For all cement composites analyzed, and the presence of $\mathrm{NdPO}_{4}$ did not appear to alter the hydration products of the cement. Grains of the $\mathrm{NaPO}_{4}$ remained tightly bonded in the cement, even through leaching, and no alteration of the structure or chemistry of the monazite structure compound was detected. Some of the desired phases were achieved with the compositionally adjusted cements. Experiments on samples cured longer than 28 days should be conclusive. 
No neodymium was detected in any of the leachates. The amounts of phosphorus detected were less than that available from the starting cements. Accelerated leaching of $\mathrm{NdPO}_{4}$ in deionized water under the same conditions has been undertaken to determine its proclivity to release phosphorus without the complcating presence of the cements.

\subsubsection{Dissolution of Tailored Ceramics}

A three-pronged investigation of the stability, dissolution, leaching, and dissolution mechanisms of the crystalline phases which are candidate components for Tailored Ceramics is underway, including (1) measurement of the dissolution of these materials at low temperatures including.a study of the dissolution mechanism, (2) measurement of the dissolution and possible breakdown of the solid phases at hydrothermal temperatures, and (3) an investigation of the surface chemistry and surface reaction layers of the leached solid phases utilizing sputter-induced optical spectroscopy as the primary characterization tool.

\subsection{Low-Temperature Dissolution of Pollucite}

Pollucite (ideal formula $\mathrm{CsAlSi}_{2} \mathrm{O}_{6}$ ) is still one of the leading crystalline hosts for the immobilization of ${ }^{137} \mathrm{Cs}$. Natural pollucite ground to -45 to -60 mesh was used for the initial experiments. In water at $25^{\circ} \mathrm{C}$ and at neutral $\mathrm{pH}$, the uptake of cesium into solution resulted in concentrations after 14 days on the order of 0.05 to $0.3 \mathrm{ppm}--$ about at the threshold of the analytical methods. Accordingly, dissolution experiments at low $\mathrm{pH}$ where dissolution rates are expected to be much higher were undertaken, with the idea to gradually increase $\mathrm{pH}$ and then extrapolate the dissolution rates into the neutral $\mathrm{pH}$ range. Under highly acid conditions, cesium, aluminum, and silicon a.1l appear in solution apparently governed by parabolic (dissolution kinetics) rate laws. 


\subsection{Other Dissolution-Related Studies}

Strontium feldspar is being considered as a possible host for ${ }^{90} \mathrm{Sr}$ in a ceramic waste form. As it is not known to occur naturally, it must be synthesized. Several methods for synthesis are being tried to determine the optimum one.

Some literature survey and other preliminary work has been done with a view to determining the stability and alkali extraction from the nepheline (ideally $\mathrm{NaAlSiO}_{4}$, usually $\sim \mathrm{Na}_{0.75} \mathrm{~K}_{0.25} \mathrm{AlSiO}_{4}$ ) phase.

\subsection{High-Temperature, High-Pressure Dissolution Apparatus}

To simulate conditions in an open system environment, candidate crystalline materials will be leached in a flowthough system at controlled pressures and temperatures.(Figure 3.1).: Water from a reservoir is pumped by a pneumatic pump into the system at a predetermined pressure. It is circulated by a metering piston pump through the reaction vessel which is heated in a furnace. Effluent from the reaction vessel may be sampled before or after the quench chamber. Solid samples may be retrieved from reaction vessel and quench chamber at the end of a run.

Several modifications were made to the equipment to extend the period between repairs and to facilitate the repairs. Also, a modification was made to improve the high-temperature sampling.

\subsection{Surface Chemistry}

Another aspect of the dissolution work is to determine how the surface chemistry of Tailored Ceramics influences dissolution processes. Sufficiently surface sensitive techniques such as sputter-induced photon spectrometry (SIPS), ion scattering spectrometry (ISS), and Auger electron spectrometry (AES) are used to determine changes in surface composition 


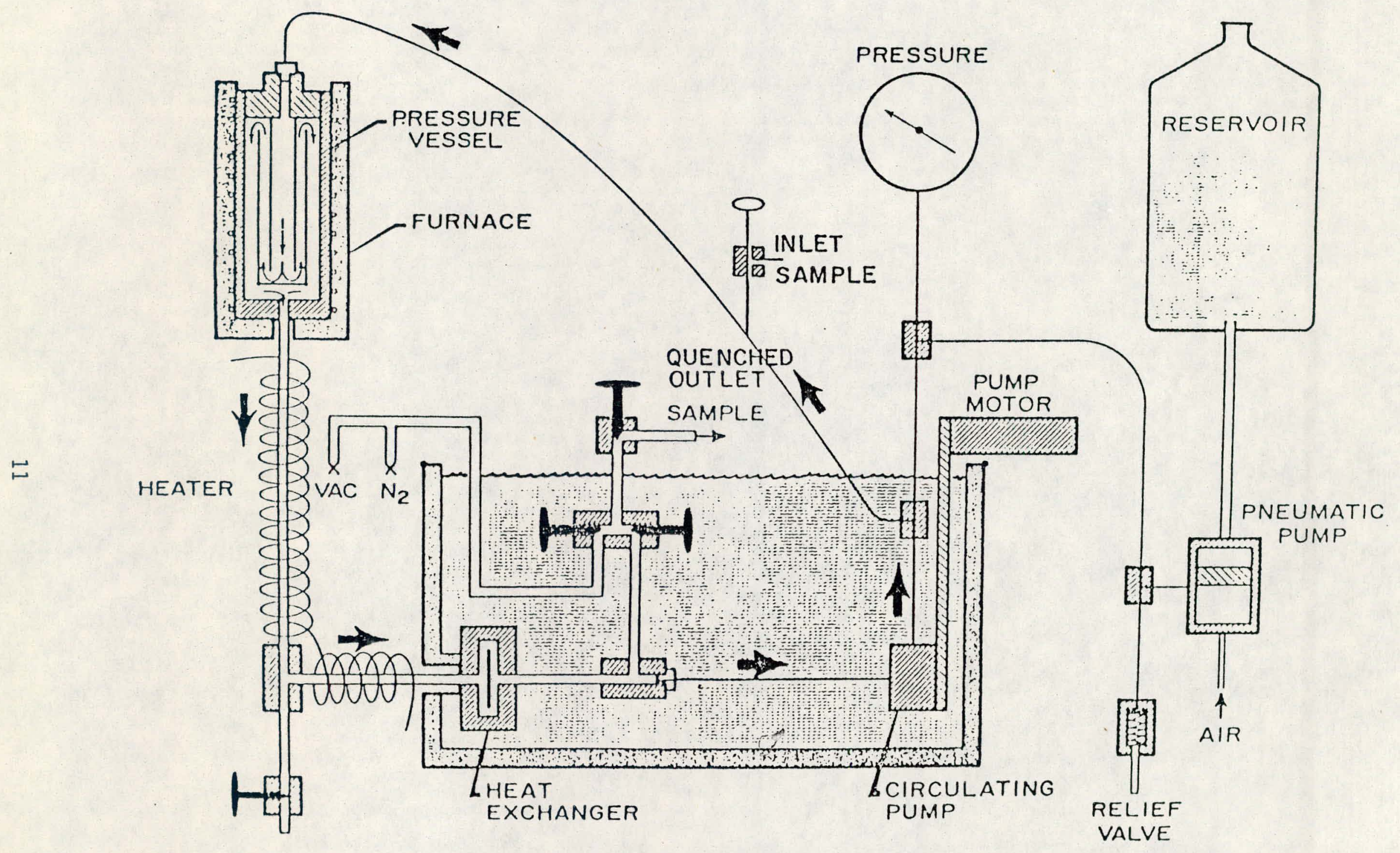

Figure 3.1. Circulating hydrothermal apparatus from H.L. Barnes, C.W. Burnham and W.F. Downs (1978) "Experimental Evaluation of Geochemical Conditions in Geothermal Energy Systems," Final Report on National Science Foundation Grant No. AER-08473. 
due to ion-exchange and/or readsorption (complexing) with solubilized species. Initial work has been undertaken using polished faces of natural monazite single crystals.

\subsubsection{Fundamental Transmutation Effects}

Combined radiation and transmutation effects may be deleterious to crystalline material under a certain combination of circumstances. The experimental design to investigate this is for first examining recognizable crystal structure effects through transmutations induced in synthetic crystalline materials. Since neutron-induced transmutations are easier to introduce in the short term than radioactive decay-induced transmutation, this program will examine the potentials of transmutation effects through the former, using Tailored Ceramic crystalline structures.

The following have been chosen as suitable for this study: $C_{s} \rightarrow B a$, $\mathrm{Sr} \rightarrow \mathrm{Y}, \mathrm{Tc} \rightarrow \mathrm{Ru}, \mathrm{In} \rightarrow \mathrm{Sn}, \mathrm{Lu} \rightarrow \mathrm{Hf}, \mathrm{Hf} \rightarrow \mathrm{Lu}, \mathrm{Rb} \rightarrow \mathrm{Sr}$, and $\mathrm{Hf} \rightarrow \mathrm{Ta}$. Of these, depending upon the ready availability of enriched stable isotopes, the $\mathrm{TC} \rightarrow \mathrm{Ru}$ and $\mathrm{Hf} \rightarrow$ Lu transmutations will be examined initially. Some detailed calculations on these isotopes have been completed. The problems associated with performing $X$-ray diffraction studies on radioactive materials are being examined using the results of these calculations. A typical set of calculated results for the transmutation experiment,

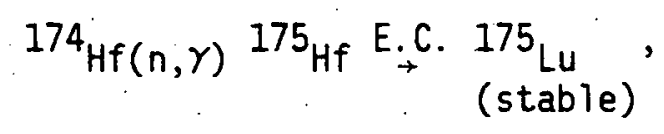

shows that it is possible to achieve about $12 \%$ conversion of the ${ }^{174} \mathrm{Hf}$ in 25 days' irradiation. This would amount to about $2.5 \%$ of total conversion of all Hf $\rightarrow$ Lu in the crystalline matrix. Another isotope of this element ${ }^{18 I_{H f}}$ is available with an artificial enrichment of $95 \%$.

This isotope undergoes the following neutron transmutation induced changes:

$$
181_{H f(n, \gamma)}{ }^{182} \mathrm{Hf} \stackrel{\text { B- }}{\rightarrow}{ }^{182} \mathrm{Ta}(\text { stable) }
$$


A 100 -day irradiation of a crystalline matrix containing ${ }^{181_{H f}}$ results in about $3.5 \%$ change in the total hafnium. Allowing adequate decay time following irradiation, this can be converted to tantalum in the crystal matrix.

A special glove box facility with a furnace is being set up to incorporate ${ }^{99}$ Tc in crystalline ceramics. Pending arrival of some of the materials, radiation effects of similar materials are being examined using a fission product spectrum source (a reactor in a shutdown mode) and a combined neutron, gamma, and electron flux of a research reactor.

$\mathrm{CsAlSi}_{2} \mathrm{O}_{6}$ (pollucite) has been put forward as a promising Cs fixer, because it is refractory and has a high leach resistance. However, the $\mathrm{C}_{s} \rightarrow \mathrm{Ba}$ transmutations could degrade the crystal integrity in a few years. Barium has low solubility in $\mathrm{CsAlSi}_{2} \mathrm{O}_{6}$. It seems possible, however, that the isomorphous compound $\mathrm{CsFeSi}_{2} \mathrm{O}_{6}$ might have host potential since the $\mathrm{Cs}^{+} \rightarrow \mathrm{Ba}^{2+}$ transmutation could be accommodated by a $\mathrm{Fe}^{3+} \rightarrow \mathrm{Fe}^{2+}$. transformation. One-day Soxhlet tests on $\mathrm{CsFeSi}_{2} \mathrm{O}_{6}$ showed -5 wt $\%$ ross for a preparation fired for $6 \mathrm{hr}$ at $1100^{\circ} \mathrm{C}$ and $\sim 1$ wt \% loss for preparations fired (1) $25^{\mathrm{h} \mathrm{hr}}$ at $1100^{\circ} \mathrm{C}$, (2) $16 \mathrm{hr}$ at $1330^{\circ} \mathrm{C}$, and (3) $28 \mathrm{hr}$ at $1400^{\circ} \mathrm{C}$. Further losses of -1 wt $\%$ per day were obtained for (2) and (3) after subsequent 3 -day Soxhlet tests. These values are far too high to be acceptable.

The preparation ( 3 ) was found to be phase-pure by $X$-ray diffraction, and an uncompacted sample of $\mathrm{CsFeSi}_{2} \mathrm{O}_{6}$ powder remained single phase after. a DTA run to a maximum temperature of $1470^{\circ} \mathrm{C}$ was carried out. These results show that the thermal stability of $\mathrm{CsFeSi}_{2} \mathrm{O}_{6}$ is satisfactory. A heat treatment of $10 \mathrm{hr}$ in $\mathrm{N}_{2}$ at $1000^{\circ} \mathrm{C}$ did not cause an observable departure from phase purity.

$\mathrm{Mn}, \mathrm{Ni}$, and $\mathrm{Co}$ analogs of pollucite were prepared, although not as yet in phase-pure form. Assuming, as found for $\mathrm{CsFeSi}_{2} \mathrm{O}_{6}$, that the 
lattice parameters were insensitive to the starting stoichiometry, the parameters of the $\mathrm{Mn}, \mathrm{Fe} ; \mathrm{Co}$, and $\mathrm{Ni}$ pollucites were found as 13.76 , $13.85,13.69,13.68($ all \pm 0.02$) \mathrm{A}$, respectively.

A natural pollucite (Smithsonian Institute, Sample 135267) was found to display no evidence for either $\mathrm{Fe}^{2+}$ or $\mathrm{Fe}^{3+}$ in solid solution. Heating for $1 / 2 \mathrm{hr}$ in air at $600^{\circ} \mathrm{C}$ was sufficient to render the intially clear crystal completely opaque. This result was presumably due to dehydration, by analogy with similar known phenomena in beryl and cordierite which occur on heating at $-800^{\circ} \mathrm{C}$. The associated change in the lattice parameter was $<0.3 \%$ after heating to $600^{\circ} \mathrm{C}$, and no further change in the parameter ensued on heating at temperatures to $1200^{\circ} \mathrm{C}$.

No effects on the X-ray patterns of $\mathrm{CsAlSi}_{2} \mathrm{O}_{6}$ and $\mathrm{CsFeSi}_{2} \mathrm{O}_{6}$ were observed after a small dose of $\gamma$-irradiation $\left(10^{9}\right.$. R). Samples are presently being neutron-irradiated to a dose of $-2 \times 10^{18}$ nvt (fast) and further samples, either mechanically mixed with $U_{3} O_{8}$ or with the $U$ dispersed as an $X$-ray amorphous phase, have been prepared for fissionfragment irradiation.

A crystalline material that will accommodate ${ }^{90} \mathrm{Sr}$ and its decay products is being designed. The host must satisfy the usual requirements of a nuclear waste form plus the two criteria of being able to accommodate the decrease in ionic radius upon decay of radioactive ${ }^{90} \mathrm{Sr}^{+2}\left(\begin{array}{ll}1.26 \mathrm{~A} \\ \text { ) }\end{array}\right.$ to radioactive ${ }^{90} \mathrm{Y}^{+3}(1.02 \mathrm{~A})$ to stable ${ }^{90} \mathrm{Zr}^{+4}(0.84 \mathrm{~A})$, and being able to accommodate the change in valence states as shown above through some charge compensation mechanism.

One possible way to do this is to incorporate $\mathrm{Sr}$ into a crystali ine solution phase that can also dissolve appreciable amounts of $Y$ and $Z r$. The first attempt was to try to incorporate Sro into crystalline solution with $\mathrm{ZrO}_{2}$. Sro was found to be insoluble (less than 1 mole percent) in $\mathrm{ZrO}_{2}$ forming a two-phase mix of $\mathrm{SrZrO}_{3}$ and $\mathrm{ZrO}_{2}$ at ali compositions investigated. 
The second attempt sought to determine the limits of crystalline solubility of $\mathrm{SrO}, \mathrm{Y}_{2} \mathrm{O}_{3}$, and $\mathrm{ZrO}_{2}$ in the rare earth (RE) oxides $\mathrm{La}_{2} \mathrm{O}_{3}$, $\mathrm{CeO}_{2}, \mathrm{Nd}_{2} \mathrm{O}_{3}, \mathrm{Gd}_{2} \mathrm{O}_{3}$, and $\mathrm{Y}_{2} \mathrm{O}_{3}$. Again, however, Sro was found to have negligible solubility forming a two-phase mixture of $\mathrm{RE}_{2} \mathrm{O}_{3}$ and an unknown Sro- $\mathrm{RE}_{2} \mathrm{O}_{3}$ compound of low symmetry. These unknown compounds have been synthesized and are being characterized by powder diffraction techniques.

The third attempt at finding a suitable host for ${ }^{90} \mathrm{Sr}$ fixation was to try to incorporate $\mathrm{Sr}$ into a synthetic garnet of the approximate composition $\mathrm{SrCa}_{2} \mathrm{Fe}_{2} \mathrm{Si}_{3} \mathrm{O}_{12}$. Experimental work has commenced and is now underway.

Monazite appears to be very resistant to metamictization from dissolved $\alpha$-emitters, but after a critical radiation dose monazite might be rendered semi-amorphous and then not recrystallize as recognizable monazite when annealed.

Ce and La monazites, doped with up to 5 mole percent natural $U$, are presently being irradiated with neutrons. U-doped huttonite and zircon, produced by the usual calcination/firing technique, are being similarly irradiated.

Nine natural monazites from various sources were annealed at 950 and $1100^{\circ} \mathrm{C}$ and in most cases an $X$-ray volume contraction of $\sim 1 \%$, together with sharpening of the diffraction lines, was observed. If this result can be associated with $\alpha$-recoil damage, rather than chemical zoning effects, monazite is clearly not completely immune to radiation damage.

Zirconolite $\left(\mathrm{CaZrTi}_{2} \mathrm{O}_{7}\right)$, doped with $U$, has been prepared for fissionfragment irradiation. Numerial.calculations have been made of the $a$-recoil damage which would be measured by the TRU-bearing phases in high-level waste. As an indication, if zircon incorporated all the TRU ions (hypothetically), it would be rendered amorphous (with a density decrease of $-16 \%$ ) after $-10^{4}$ years. 


\subsubsection{Formulation and Consolidation Studies}

Efforts have been focused on developing a suitable crystalline phase assemblage for simulated Savannah River Plant (SRP) defense waste which will provide a high quality Tailored Ceramic with a minimum of additives. In the initial efforts, a number of samples representing the range of compositions for simulated waste called out in the July 5 , 1979; SRL letter from J. A. Kelley to D. L. McIntosh in both untailored and tailored* forms have been made up, hot pressed, and analyzed for phase and microstructural content. The information obtained from these runs has been used to design phase compatibility studies, direct the development of new tailoring schemes, and to orient geochemical stability studies.

With aluminum and iron being the bulk cations in the SRP waste, these elements have to a great extent controlled the properties of the hot-pressed ceramics. Tailored waste samples with the Al/Fe ratio ranging from 0.14 to 22.3 have thus far been examined. Results show that at the lower extreme of $A 1 / F e$, crystalline spinel determines the ceramic properties, while a-alumina (sapphire) dominates at the other extreme. The characterization results from these samples have shown the high Ai composition to provide the most promising physical and chemical characteristics for a Tailored Ceramic waste form.

The hot-pressed pellets formed (see Figure 3.2) from the high $A 1$ tailored waste composition $\left(\mathrm{Al}_{2} \mathrm{O}_{3}=65\right.$ to 85 mole percent of calcine) are extremely hard with a density greater than $93 \%$ that of theoretical. The crystalline grains are small (2000-10,000 A) and show a very high degree of crystalline microstructural isolation. Figure 3.3 shows a bright field transmission micrograph of a hot-pressed sample made up

*That is, with selected additions to produce a ceramic with the desired phase assemblage. 


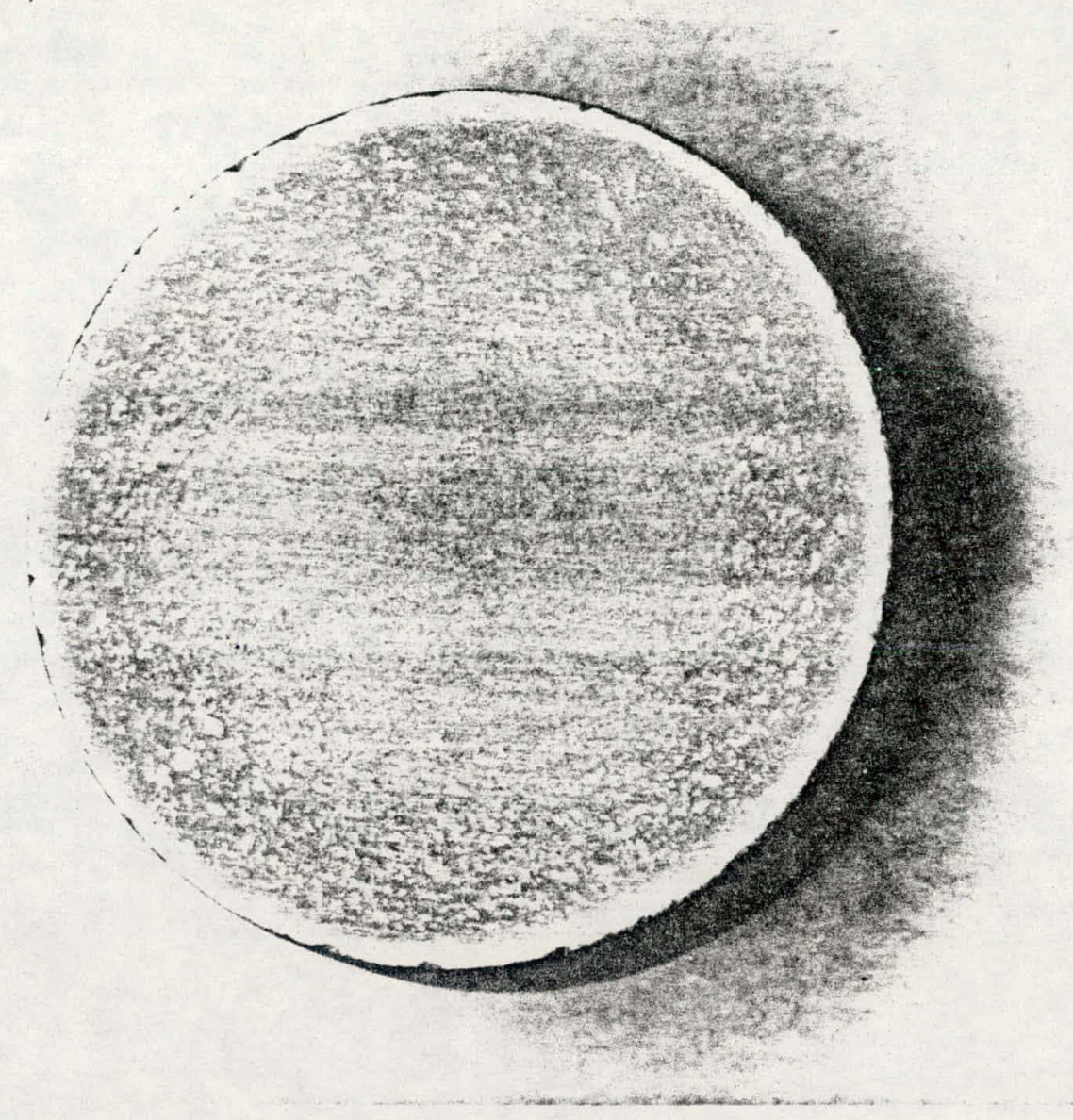

Figure 3.2. One inch diameter hot-pressed multiphase ceramic, HASR1 Mole percent composition (Calcine)

$\begin{array}{ll}\mathrm{Fe}_{3} \mathrm{O}_{3} & 3.8 \% \\ \mathrm{Al}_{2} \mathrm{O}_{3} & 84.8 \\ \mathrm{MnO}_{2} & 5.7 \\ \mathrm{U}_{3} \mathrm{O}_{8} & 0.17 \\ \mathrm{CaO} & 0.68 \\ \mathrm{NiO} & 1.7 \\ \mathrm{Na}_{2} \mathrm{O} & 3.60 \\ \mathrm{Cs}_{2} \mathrm{O} & 0.009\end{array}$

Pressing T\&P: $1400^{\circ} \mathrm{C}, 3820$ PSI

Calculated Density: $3.7833 \mathrm{G} / \mathrm{CC}$

Archimedes Density: $3.826 \mathrm{G} / \mathrm{CC}$

$\%$ Theoretical Density: $>93 \%$ 



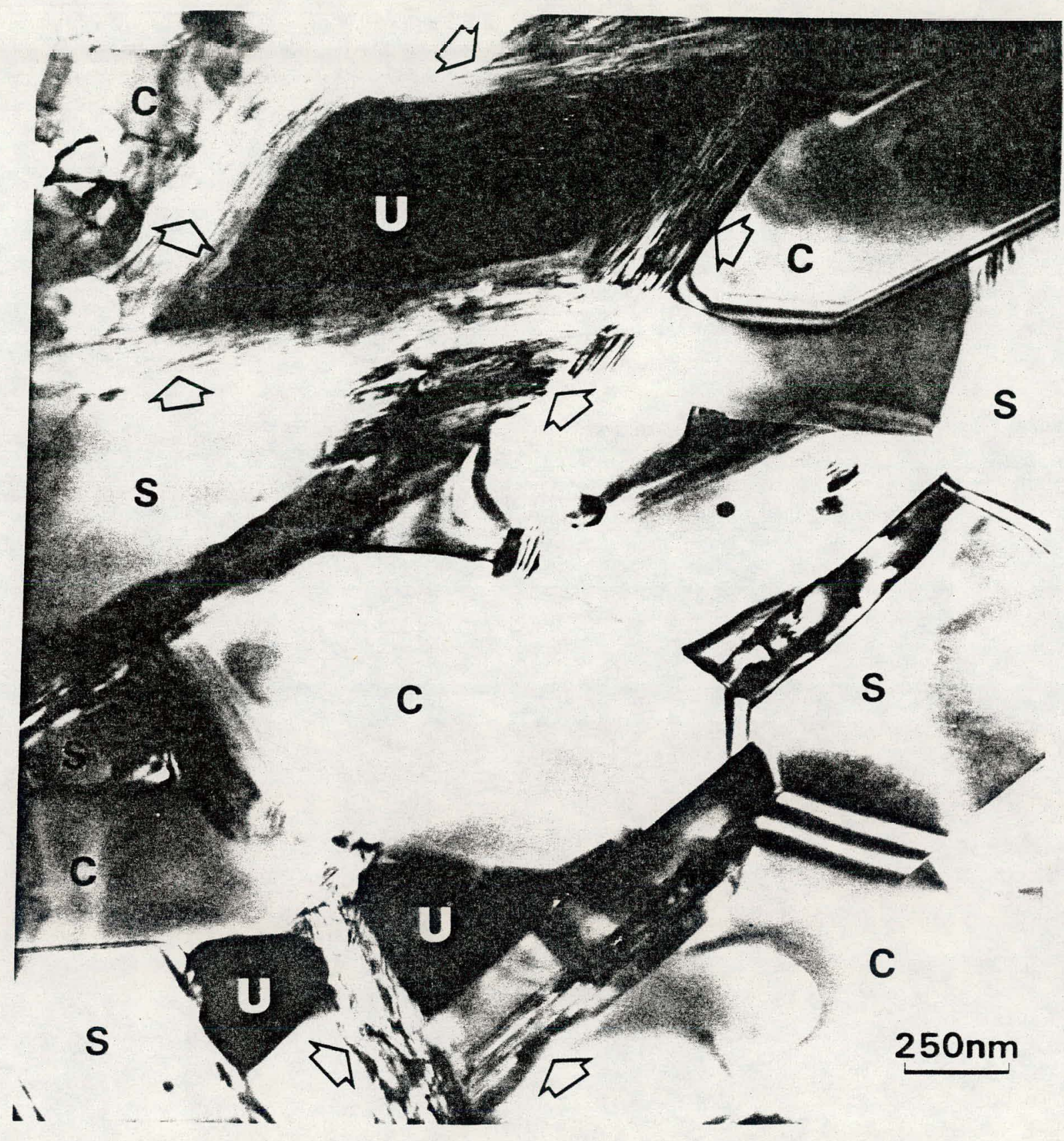

Figure 3.3. Bright field transmission micrograph of high alumina composition simulated SRP waste, sample HASRI.

$$
\begin{aligned}
& U=\text { Uraninite } \\
& C=\text { Corundum } \\
& S=\text { Spinel } \\
& U=\text { Magnetoplumbite }
\end{aligned}
$$



from Kelley's high Al (without Al removal) composition and without the addition of Ion Siv IE95. The micrograph illustrates the dense, polyphase nature of the ceramic. The four constitutent phases present are $(\mathrm{Fe}, \mathrm{Mg})$ spinel (hercynite) labelled S, $\alpha$-alumina (sapphire) labelled $\mathrm{C}, \mathrm{UO}_{2}$ uraninite labelled $U$, and magnetoplumbite shown with arrows. No continuous intergranular glassy phase is present and each phase is microstructurally isolated from others of the same type. SIMS analysis of this sample showed CS to be retained during hot pressing and STEM analysis indicated that it is primarily located in the magnetoplumbite structure. Work is continuing with a number of high Al compositions to optimize hot-pressing parameters and to determine the effects of adding ranges of trace elements and Ion Siv IEg5.

To establish the basic phase compatibility relationships controlling the ceramic formation, studies have been initiated on the $\mathrm{CaO}-\mathrm{Fe}_{2} \mathrm{O}_{3}-$ $\mathrm{Nd}_{2} \mathrm{O}_{3}$ and $\mathrm{CaO}-\mathrm{Fe}_{2} \mathrm{O}_{3}-\mathrm{Al}_{2} \mathrm{O}_{3}$ phase diagrams. Preliminary leach testing experiments at $90^{\circ} \mathrm{C}$ in distilled water have been started on samples of hot-pressed high $A 1$ waste.

\subsubsection{Radiation and Transmutation Effects}

This task was initiated to study the effects of nuclear decay radiation and transmutations on Tailored Ceramic waste forms now under development. The objective is to carry out a series of irradiation experiments that simulate radiation and transmutation effects in proposed Tailored Ceramic materials on an accelerated time scale. The results will be used to assess the durability of Tailored Ceramics in isolating nuclear waste nuclides from the environment over a geologic time scale.

Results of the initial program effort included the establishment of a program plan and key contacts with other researchers in the field, the initiation of a detailed literature review of the radiation damage field as applied to nuclear waste forms, and a start on formulating the program's first radiation damage experiments. 
A literature review on radiation and chemical effects on nuclear waste forms was initiated during the report period. The objective of this background research is to establish a firm foundation for planning the experimental program and the interpretation of the results. The literature review emphasizes the simulation of radiation effects in high-level nuclear waste forms; radiation effects on covalent (plus some ionic) metal oxides which are basic constituents of proposed Tailored Ceramic waste oxide compositions; the formation and properties of the metamict state; and the effects of alpha particles on naturally occurring minerals. A draft report entitled "The Simulation of Radiation Effects in High-Level Nuclear Waste Forms" is in preparation. "This review covers work on glass as well as crystalline waste forms. A second draft report reviewing radiation damage effects in naturally occurring minerals has been initiated.

Work has begun on formulating the program's first radiation damage experiments. It appears at present that these experiments will be reactor neutron irradiations of doped Tailored Ceramic crystalline phases, with the dopants consisting of one or more isotopes with large thermal-energy neutron cross sections. The major effects these experiments will simulate include alpha-decay and recoil nucleus damage and transmutation damage. The phases to be investigated, and the dopants and doping procedures to be used, will depend in large measure on those phases selected under the Task 2 and Task 3 program efforts to host key waste radionuclides. Attractive choices at present include ${ }^{6} \mathrm{Li}$ doping of a spinel phase and ${ }^{10} B$ interstitial doping in monazite.

A spent thermoelectric generator, with a ${ }^{90} \mathrm{Sr}$ heat source has been located with the cooperation of the Department of Energy. The ${ }^{90} \mathrm{Sr}$ is incorporated in the crystalline phase ${ }^{90} \mathrm{SrTiO}_{3}$, a form of the mineral phase perovskite. This mineral is similar to some crystalline phases proposed in Tailored Ceramics formulations. About $35 \%$ of the ${ }^{90} \mathrm{Sr}$ in the source has decayed to the stable nuclide ${ }^{90} \mathrm{Zr}$ in the 20 years since 
this source was manufactured. The source thus appears to provide an ideal opportunity to study transmutation damage in a single-phase crystalline material. Means to acquire this source are now being pursued.

\subsubsection{Geologic Strata Compatibility}

This task had not been initiated during the quarter being reported.

\subsection{PROCESS AND EQUIPMENT DEVELOPMENT}

\subsubsection{Engineered Containment}

The results of the trade study currently in progress will be used to guide the development of the process(es) for consolidation of Tailored Ceramics and the loading of canisters with the dense ceramic bodies. The process will be constrained to mate with the SRL process flow diagram and to utilize both the waste materials separation processes and the final clean canister handling process.

Investigations of current technology have begun with the review and assessment of published reports. In conjunction with this review, a file has been established for the collection and cross-referencing of pertinent report data.

A trade study whose thrusts are to identify the critical process parameters involved in the production and the containment of consolidated Tailored Ceramic waste forms, and to optimize the canister size, weight, heat load, and matrix material selection combinations has been initiated.

\subsubsection{Process Evaluation and Definition}

Process flow diagrams of increasing complexity will be prepared for promising process sequences leading to the issuance of a report at the 
end of the fiscal year. Order of magnitude cost estimates will be prepared on the more promising process sequences. In all cases, these sequences will' utilize the existing SRL front-end waste removal and stream separation process steps.

Calcination studies of waste compositions containing aluminates will be performed to evaluate the feasibility of producing a calcine which can be consolidated at an acceptable temperature to form a dense Tailored Ceramic body.

Waste technology reports have been assessed for their applicability to the Tailored Ceramic process. Information on the specific wastes to be immobilized is undergoing evaluation. The need for the removal of aluminum from the waste is in question, with the thought that its ceramic end products, $\mathrm{Al}_{2} \mathrm{O}_{3}$ and $\mathrm{Al}$-spinels, are very stable ceramic species and are quite acceptable as final chemical forms. One critical parameter in these considerations is the minimum satisfactory consolidation (sintering) temperature at which a dense closed-pore ceramic containing possible high amount of $\mathrm{Al}_{2} \mathrm{O}_{3}$ either as corundum or in a spinel can be formed from the waste calcine.

Preliminary flow diagrams and material balances are being developed for processes in which the alumina is not removed from the waste. These sequences involve the use of the existing SRL plan for removing the supernate and the sludge fractions from the waste tanks, an additive "tailoring" step, a calcination step, and a calcine densification step (such as extrusion or cold pressing) to form a body which is hot pressed (either uniaxially or isostatically). The logistics of the sizes and the numbers of pressings, and of process lines, are being examined in the Task 6 trade. study. 
In the considerations of the "alumina-in" process sequence, it is evident that a highly sinterable alumina must be produced in the calcination step in order that the final hot pressing be possible at tractable temperatures $\left(1200^{\circ} \mathrm{C}\right.$, as a nominal maximum). Accordingly a test study of the calcination process step has been initiated using guidance from Task 3.

737-H.60/ebs 
